\title{
METODA OPREDELITVE ŠTEVILA FUNKCIONALNIH REGIJ: APLIKACIJA NA RAVNEH NUTS 2 IN NUTS 3 V SLOVENIJI
}

A METHOD TO DEFINE THE NUMBER OF FUNCTIONAL REGIONS: AN APPLICATION TO NUTS 2 AND NUTS 3 LEVELS IN SLOVENIA

\section{Samo Drobne, Marija Bogataj}

UDK: 330.3:711.2

\section{IZVLEČEK}

$V$ prispevku predlagamo metodo za opredelitev števila in sestave funkcionalnih regij $v$ državi. Pri metodi za odločanje glede števila funkcionalnih regij se upoštevata zahteva po bolj izenačeni vrednosti ekonomskih kazalnikov med regijami (povprečna variabilnost bruto plače na prebivalca med regijami naj bo minimalna) ter evropsko priporočilo glede števila prebivalcev $v$ regiji. S predlagano metodo smo analizirali regije na ravneh NUTS 2 in NUTS $3 v$ Sloveniji v obdobju 2000-2010. Vaplikaciji predlagane metode smo iskali podobno razvite regije (čim manjšo neenakost med regijami).

\section{KLJUČNE BESEDE}

regija, funkcionalna regija, vožnja na delo, odločanje, število funkcionalnih regij, NUTS 2, NUTS 3, Slovenija
Klasifikacija prispevka po COBISS-u: 1.01

\begin{abstract}
In the article, we suggest a method of decisionmaking about the number and composition of functional regions in the state. The method considers the economic variable of the average monthly gross earnings per capita in the functional region (the variability between regions should be minimal) as well as the guidelines for the population size of the regions. The method was applied to analyse regions at NUTS 2 and NUTS 3 levels in Slovenia in 2000-2010. In our application we are looking for equally developed regions (with the smallest disparities between regions possible).

\section{KEY WORDS}

region, functional region, commuting, decisionmaking, number of functional regions, NUTS 2, NUTS 3, Slovenia
\end{abstract}

\section{UVOD}

Koncept regij je globoko zasidran v zgodovini Evrope. Še preden je tehnologija prometa omogočila nastanek in povezovanje nacionalnih trgov, so večino Evrope sestavljale gospodarsko avtonomne regije, katerih velikost je bila omejena $\mathrm{z}$ enodnevno dostopnostjo do regionalnega središča peš ali z vozom z vprego. Le najbolj razvita mesta in mestne regije, predvsem obmorske, so lahko premostili fizične razdalje in postali del višjerazrednih, vseevropskih, trgovskih in drugih struktur moči. Šele proti koncu predindustrijske dobe so centralizirana državna gospodarstva zaradi krepitve osrednje birokratske moči nadomestila srednjeveške regije. Kasneje pa je proces etatizacije po Evropi dobil različne oblike (Maier, 2005).

Danes se pojem regij pogosto nanaša na povezovanje v okviru Evropske unije (EU). Toda sam koncept regije različni akterji razumejo zelo različno. Administrativne in statistične regije so opredeljene z nominalno določenimi mejami, homogeno naj bi pokrivale celoten pripadajoči 
teritorij in bile primerljive velikosti. $\mathrm{V}$ nasprotju s togimi administrativnimi regija pa so funkcionalne regije nekega gospodarstva in/ali družbe proizvod medsebojnih odnosov, ki se z razvojem tehnologij in investicij v prostor spreminjajo, so zelo raznolike v smislu velikosti in števila prebivalstva, lahko se prekrivajo, po drugi strani pa tudi ni nujno, da homogeno prekrijejo celotno obravnavano ozemlje.

Ball (1980), Casado-Diaz (2000), Andersen (2002) in Karlsson in Olsson (2006) so pokazali, da standardno opredeljene administrativne regije, ki jih države uporabljajo za oblikovanje politike, dodeljevanje virov in raziskave, ne dajejo popolnih informacij o dejanskih razmerah v nekem kraju ali regiji. Zato se je pojavila težnja po opredelitvi in zamejitvi funkcionalnih regij. Funkcionalna regija je regija, za katero je značilna strnjenost dejavnosti in notranje prometne infrastrukture, ki omogoča veliko mobilnost ljudi, proizvodov in naložb znotraj meja medsebojnega vpliva. Poglavitna značilnost funkcionalne regije je integrirani trg dela, na katerem so dnevna mobilnost delavcev, iskanje zaposlitve in povpraševanje po delu v regiji veliko bolj intenzivni kot med regijami (Laan in Schalke, 2001; Karlsson in Olsson, 2006). Prepoznavanje in zamejitev funkcionalnih regij sta zato pogosto odvisna od razmer na lokalnih trgih dela (Smart 1974; Coombes in sod., 1986; Casado-Diaz, 2000; OECD, 2002; Karlsson in Olsson, 2006; Cörvers in sod., 2009; Farmer, 2009 ) in jih gospodarski pretresi, kot je zadnja kriza, lahko porušijo. ${ }^{1}$

Cilj funkcionalne regionalizacije je torej opredeliti geografske enote, $\mathrm{v}$ katerih poteka večina interakcij med delavci, ki iščejo zaposlitev, in delodajalci, ki zaposlujejo (tj. opredeliti meje, prek katerih relativno malo ljudi potuje med svojim domom in delovnim mestom). Takšne funkcionalno sklenjene regije so zanimive za ekonomiste dela, ki opravljajo raziskave na različnih regionalnih in lokalnih ravneh, ter za različne službe državne, regionalne in lokalne uprave (Ball, 1980; Casado-Diaz, 2000). Prav tako so tokovi delavcev vozačev pomembni pri načrtovanju prometa, bivališč in druge infrastrukture. Lokalni trgi dela (tj. funkcionalne regije na lokalni ravni) so bili spoznani kot glavno merilo za merjenje razmer na trgu dela, zato so idealna geografska območja za poročanje razčlenjenih številk o trgu dela in prepoznavanje območij, ki jim namenjamo različne pomoči. V Združenem kraljestvu so funkcionalno opredeljene regije uporabili tudi za reorganizacijo lokalne uprave, v Italiji pa za razmejitev industrijskih območij (Casado-Diaz, 2000).

V literaturi je mogoče zaslediti več različnih postopkov funkcionalne regionalizacije (npr. Masser in Brown, 1975, 1977; Slater, 1981; Coombes in sod., 1986; Florez-Revuelta in sod., 2008; Farmer in Fotheringham, 2011). Nedavno je bil v Karlsson in Olsson (2006) opravljen pregled različnih pristopov k razmejitvi funkcionalnih regij. Po drugi strani Farmer in Fotheringham (2011) prepoznavata tri splošne skupine postopkov funkcionalne regionalizacije: (1) hierarhično razvrščanje v skupine (angl. hierarchical clustering), (2) večstopenjsko združevanje (angl. multistage aggregation) in (3) združevanje okoli središč (angl. central place aggregation). Ne glede na pristop oziroma metodo pa je cilj postopkov funkcionalne regionalizacije opredeliti

${ }^{I}$ Nekatere študije primera zamejitve funkcionalnih regij so v Mitchell in sod. (2007) za Avstralijo, v Persyn in Torfs (2011) za Belgijo, $v$ Tomaney in Ward (2000); Feldman in sod. (2006); Bond in Coombes (2007) za Anglijo, Wales in Škotsko, v Papps in Newell (2002) za Novo Zelandijo, $v$ Laan (1991); Van der Zwan in sod. (2005); Cörvers in sod. (2009) za Nizozemsko, v Karlsson in Olsson (2006) za Švedsko, v Casado-Diaz (2000) za Španijo, v Killian in Tolbert (1993) za Združene države Amerike in v novejših študijah za Slovenijo v Drobne in sod. (2009a, 2009b, 2010); Drobne in Konjar (2011); Konjar (2009); Konjar in sod. (2010); Pogačnik in sod. (2009, 2011); Bajt (2010). 
čim več možnih funkcionalnih regij, za katere veljajo določene operativne in statistične omejitve (Farmer, 2009).

Glavna omejitev številnih postopkov funkcionalne regionalizacije pa se kaže v nezmožnosti za neposreden izbor števila funkcionalnih regij $k$. Nedavno je Farmer (2009) izdelal pregled pristopov k opredelitvi števila funkcionalnih regij: (1) nekateri pristopi zahtevajo, da je vrednost števila funkcionalnih regij $k$ določena a priori (npr. Brown in Holmes, 1971; Masser in Scheurwater, 1980; Cörvers in sod., 2009), (2) pri drugih pristopih se $k$ določi z uporabo ad hoc ocen podatkov, pri čemer subjektivne ocene konfiguracije funkcionalnih regij pogosto temeljijo na avtorjevem dojemanju lokalnih okolij in posebnih vsebin aplikacije za določitev optimalnega števila funkcionalnih regij (Farmer, 2009), (3) v tretjo skupino spadajo mrežne metode, s katerimi se opredeli skupnostna struktura neke mreže. ${ }^{2}$

Kot smo omenili, je pristopov za zamejitev funkcionalnih regij več. V tem članku analiziramo funkcionalne regije v Sloveniji, opredeljene s hierarhičnim razvrščanjem v skupine po metodi Intramax (Masser in Brown, 1975, 1977; Masser in Scheurwater, 1980) z izvirnim dodajanjem družbeno-ekonomskih kriterijev, jih primerjamo z administrativnimi regijami na ravneh NUTS 2 in NUTS 3 v Sloveniji ter predlagamo metodo za odločanje o številu funkcionalnih regij $\mathrm{v}$ državi. Funkcionalne regije so po značaju heterogene, saj delavci vozači prihajajo z območij z manj delovnimi mesti na območja z večjo ponudbo dela. Predlagana metoda za opredelitev "primernega« števila funkcionalnih regij v državi temelji na iskanju (lokalnih) minimumov v variabilnosti družbeno-ekonomskih parametrov, ki vplivajo na kriterialno funkcijo, med regijami (oziroma (lokalnih) maksimumov v variabilnosti parametrov v regijah). V aplikaciji predlagane metode analiziramo administrativne regije na ravneh NUTS 2 in NUTS 3 v Sloveniji. Slovenija se je leta 2004 priključila EU. Zato smo za aplikacijo predlagane metode izbrali naslednja dvoletna časovna obdobja: 2000-2001, 2004-2005 ter zadnje obdobje, za katero so bili na voljo podatki, to je obdobje 2009-2010. Izbor takšnega časovnega obdobja analize omogoča tudi ugotavljanje vpliva gospodarske krize na sestave funkcionalnih regij v državi.

\subsection{NUTS-regije v Sloveniji}

Razvrstitev NUTS (nomenklatura statističnih teritorialnih enot) je hierarhičen sistem za členitev gospodarskega ozemlja EU za potrebe (a) zbiranja, razvoja in usklajevanja regionalnih statistik EU; (b) družbeno-ekonomskih analiz regij in (c) oblikovanja regionalnih politik EU (ES, 2003; 2007). Za namene družbeno-ekonomskih analiz so bile vzpostavljene tri ravni regij znotraj vsake države članice EU: (b1) velike družbeno-ekonomske regije na ravni NUTS 1, (b2) osnovne regije za izvajanje regionalnih politik na ravni NUTS 2 in (b3) manjše regije za izvajanje posebnih analiz na ravni NUTS 3. Za potrebe oblikovanja regionalnih politik EU so bile: (c1) regije, upravičene do pomoči iz strukturnih skladov (cilj 1), uvrščene na raven NUTS 2; (c2) regije, upravičene na podlagi drugih prioritetnih ciljev, so bile večinoma uvrščene na raven NUTS 3; (c3) kohezijsko poročilo pa je bilo do zdaj večinoma pripravljeno na ravni NUTS 2. V sedanji

\footnotetext{
${ }^{2}$ Skupnostna struktura se oblikuje tako, da se vozlišča v mreži oblikujejo v skupine visoke povezanosti po povezavah znotraj skupine ter nizke povezanosti po povezavah med skupinami. V mrežnih metodah ciljna funkcija $Q$ neposredno meri kakovost določene razvrstitve $v$ skupine, kar omogoča samodejno izbiro optimalnega števila skupin (ali funkcionalnih regij) $k v$ mreži, z izborom take razporeditve skupin, da je $Q$ maksimalen (Farmer, 2009; Farmer in Fotheringham, 2011).
} 
klasifikaciji NUTS, veljavni od 1. januarja 2008 do 31. decembra 2011, je 97 regij na ravni NUTS 1, 271 regij na ravni NUTS 2 in 1303 regije na ravni NUTS 3 (Eurostat, 2011). Na ravni NUTS 0 so opredeljene državne meje držav članic EU.

V Sloveniji je na ravni NUTS 0 in NUTS 1 samo ena regija: celotna država. Za izvajanje regionalnih politik na ravni NUTS 2 je Slovenija razdeljena v dve regiji, imenovani tudi »makroregiji« ali »kohezijski regiji«, na ravni NUTS 3 pa je Slovenija členjena v dvanajst »statističnih regij«, imenovanih tudi »razvojne regije« (SORS, 2011a; glej sliko 1). Vzhodna (SI01) in zahodna (SI02) kohezijska regija sta bili predlagani z Zakonom o spodbujanju skladnega regionalnega razvoja, leta 2005 ju je potrdila Vlada Republike Slovenije. V Vzhodni Sloveniji so naslednje razvojne regije (na ravni NUTS 3): Pomurska regija (01), Podravska regija (02), Koroška (03), Savinjska regija (04), Zasavska regija (05), Spodnjeposavska regija (06), Jugovzhodna Slovenija (07) in Notranjsko-kraška regija (10). V Zahodni Sloveniji so naslednje razvojne regije (na ravni NUTS 3): Osrednjeslovenska regija (08), Gorenjska regija (09), Goriška regija (11) in Obalno-kraška regija (12). Medtem ko kohezijski regiji obstajata šele od 1. januarja 2008, je prva različica statističnih regij nastala že v sredini 70. let prejšnjega stoletja. Takrat so bile statistične regije določene za potrebe regionalnega planiranja in sodelovanja med različnimi sektorji. Prva regionalizacija statističnih regij je temeljila na izčrpni analizi gravitacijskih območij trgov dela, gravitacijskih območij učencev, dijakov in študentov ter gravitacijskih območij ponudbe in povpraševanja po blagu in storitvah $\mathrm{v}$ dvanajstih regijskih in podregijskih središčih; to je tudi razlog, da so bile slovenske regije na ravni NUTS 3 dolgo zelo stabilne (SORS, 2011a). Slika 1 prikazuje dve kohezijski regiji, dvanajst statističnih regij in 210 občin v Sloveniji na začetku leta 2011.

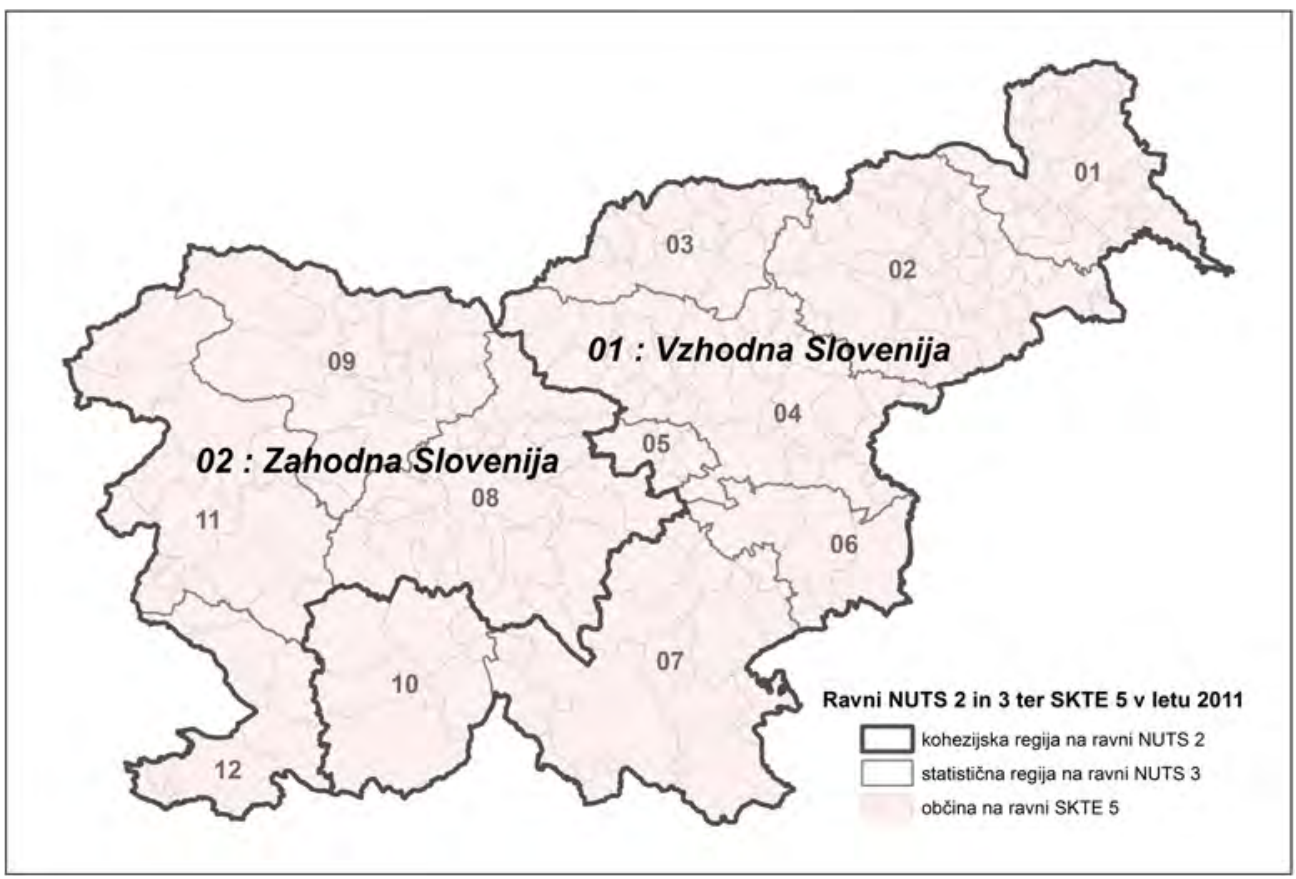

Slika 1: Dve kohezijski regiji in dvanajst statističnih regij v Sloveniji na začetku leta 2011 (ES, 2003, 2007; Eurostat, 2010; SORS, 2011a). 


\section{GRADIVO IN METODOLOGIJA}

Delavec vozač (tudi delovni migrant) je zaposlena oseba, katere teritorialna enota delovnega mesta ni enaka teritorialni enoti prebivališča. Za potrebe naše aplikacije smo izvedli analizo medobčinskih delavcev vozačev v Sloveniji. Vir podatkov je bil Statistični register delovno aktivnega prebivalstva (SRDAP), ki ga vodi Statistični urad Republike Slovenije (SURS). V SRDAP so vključene zaposlene osebe, ki prejemajo plačo, ali samozaposlene osebe, ki so stare vsaj 15 let in so na podlagi pogodbe o zaposlitvi obvezno socialno zavarovane oziroma so v delovnem razmerju na območju Republike Slovenije. Pogodba o zaposlitvi je lahko sklenjena za nedoločen ali določen čas, s polnim delovnim časom ali z delovnim časom, krajšim od polnega (SORS, 2011b).

Tu bi želeli navesti dve metodološki opombi; prvič, v obravnavanem obdobju 2000-2010 se je število občin dvakrat spremenilo: leta 2002 je bila ustanovljena ena nova občina, leta 2006 pa sedemnajst novih občin. Število obravnavanih občin je bilo torej: 192 občin v obdobju 2000-2001, 193 občin v obdobju 2002-2005 in 210 občin v obdobju 2006-2010. In drugič: v SRDAP-ovih podatkih za obdobje 2000-2008 je za prebivalce Republike Slovenije upoštevano stalno prebivališče, za tujce pa zgolj začasno prebivališče. Od leta 2009 pa je za vse osebe najprej upoštevano začasno prebivališče in šele nato njihovo stalno prebivališče.

$\mathrm{Za}$ analizo funkcionalno opredeljenih regij ter njihovo primerjavo $\mathrm{z}$ normativno določenimi regijami na ravni NUTS 2 in NUTS 3 v Sloveniji smo funkcionalne regije modelirali z metodo Intramax, ki spada med metode hierarhičnega razvrščanja v skupine. Postopki regionalizacije, ki temeljijo na hierarhičnem razvrščanju v skupine, so se prvič pojavili v 70. in 80. letih prejšnjega stoletja kot alternativa bolj ad hoc metodam. Metode hierarhičnega razvrščanja v skupine vključujejo tehnike markovskih verig po Brown in Holmes (1971) kot tudi pristope po Masser in Brown $(1975,1977)$ ter Masser in Schuerwater (1980), ki temeljijo na izboljšavah Wardovih (1963) postopkov hierarhičnega združevanja (Farmer, 2011).

Metoda Intramax, ki sta jo uvedla Masser in Brown (1975) in jo nekaj let kasneje še izboljšala (Masser in Brown, 1977; Masser in Schuerwater, 1980), izvaja regionalizacijo na podlagi matrike interakcij. Cilj metode Intramax je maksimizirati delež v skupini interakcij v vsakem koraku združevanja v skupine, ob upoštevanju variacij v seštevkih vrstic in stolpcev v matriki interakcij. V postopku združevanja v skupine se v vsakem koraku združi par območij, v našem primeru občin, pri katerih ima ciljna funkcija $T$ najvišjo vrednost (Breukelman in sod., 2009):

$\max T$,

$$
T=\frac{T_{i j}}{O_{i} \cdot D_{j}}+\frac{T_{j i}}{O_{j} \cdot D_{i}},
$$

kjer $T_{i j}$ predstavlja interakcijo med izvorom $i$ in ponorom $j, O_{i}=\sum T_{i j}$ je seštevek vseh interakcij po izvoru $i, D_{j}=\sum T_{i j}$ je seštevek vseh interakcij po ponoru $j$ ter $\dot{D}_{j}>0$. Pri tem število interakcij razumemo kot števiilo potovanj na delo v skladu s predhodnim opisom.

Analiza Intramax se izvede po korakih. V vsakem koraku se združi par območij, med katerimi je delež interakcij največji, in interakcija med tema območjema postane notranja interakcija za 
novo, združeno območje. V naslednjem koraku prevzame to novo, združeno območje vlogo prejšnjih dveh območij. Ta postopek se ponavlja, dokler ni vseh $N$ območij po $N-1$ koraku združenih v eno območje (regijo) in vse interakcije postanejo notranje.

V analizi smo funkcionalne regije v Sloveniji modelirali s programom Flowmap (Breukelman in sod., 2009), ki vsebuje algoritem metode Intramax. V programu Flowmap je rezultat modeliranja po postopku Intramax poročilo v obliki preglednice in dendrograma, ki kaže, katere občine so združene v funkcionalno regijo in kako so združene. Za vsako obravnavano leto (2000, 2001, 2004, 2005, 2009 in 2010) smo modelirali 29 sistemov z od 2 do 30 funkcionalnimi regijami (skupno torej 174 sistemov funkcionalnih regij). Te sestave funkcionalnih regij smo uporabili za razvoj meril za odločanje o »primernem« številu funkcionalnih regij v Sloveniji. Pri tem smo upoštevali (a) demografsko merilo smernic EU glede velikosti regij na ravni NUTS 2 in NUTS 3 ter (b) merilo podobne ekonomske razvitosti regij.

V preglednici 1 so podane smernice EU glede velikosti regij na ravneh NUTS. Pragovi, podani v preglednici, so smernice za določitev regije, vendar se ne uporabljajo dosledno.

\begin{tabular}{|c|c|c|}
\hline Raven & $\begin{array}{c}\text { Najmanǰ̌s število prebivalcev } \\
\text { v regiji }\end{array}$ & $\begin{array}{c}\text { Največje število prebivalcev v } \\
\text { regiji }\end{array}$ \\
\hline NUTS 1 & 3.000 .000 & 7.000 .000 \\
\hline NUTS 2 & 800.000 & 3.000 .000 \\
\hline NUTS 3 & 150.000 & 800.000 \\
\hline
\end{tabular}

Preglednica 1: Smernice glede ustanovitve regij na ravneh NUTS 1-3 (ES, 2003; Eurostat, 2011).

Najbolj pogosto uporabljeno ekonomsko merilo v različnih analizah regionalnega razvoja je bruto domači proizvod (BDP). Gospodarsko uspešnost lahko določimo na tri načine, ki bi praviloma morali dati enak rezultat. To so proizvodni pristop (metoda dodane vrednosti), dohodkovni pristop in izdatkovni pristop. Dohodkovni pristop meri BDP kot vsoto dohodkov, ki jih podjetja plačujejo gospodinjstvom za proizvodne dejavnike najema, plač za delo, obresti za kapital, rent in dobička od podjetništva. Praviloma se BDP meri le za regije na ravni NUTS 3 ali višje. Podatkov o BDP za nižje regionalne ravni ni. Zato smo kot merilo gospodarske uspešnosti izbrali povprečno mesečno bruto plačo na osebo, zaposleno pri pravnih osebah, v občini ponora tokov (SORS, 2011c). Povprečna mesečna bruto plača na prebivalca $v$ funkcionalni regiji je izračunana kot:

$$
\begin{aligned}
& G E A R_{-} P C(f r)=\frac{\sum_{f r} G E A R_{-} P E(m) \cdot P P E(m)}{P O P(f r)}, \\
& P O P(f r)=\sum_{f r} P O P(m),
\end{aligned}
$$

kjer je $G E A R \_P E(m)$ povprečna mesečna bruto plača na osebo, zaposleno pri pravnih osebah, v občini, $P P E(m)$ je število zaposlenih oseb v občini $m, P O P(f r)$ je število prebivalcev v funkcionalni 
regiji, $P O P(m)$ je število prebivalcev v občini in $\sum_{f r} \cdot$ označuje vsoto po občinah, ki jih pripišemo funkcionalni regiji $f r$.

Model odločanja o številu funkcionalnih regij na ravneh NUTS 2 in NUTS 3 temelji na variabilnosti povprečne mesečne bruto plače na prebivalca med funkcionalnimi regijami in odklonom števila prebivalcev v funkcionalni regiji glede na smernice EU:

$$
\begin{aligned}
& \min _{k} f(k, w) \\
& f=w \cdot C V_{G E A R_{-} P C(f r)}+(1-w) \cdot C D_{P O P(f r)},
\end{aligned}
$$

kjer je $k$ število funkcionalnih regij v državi, $C V_{G E A R} P C(f r)$ je koeficient variacije povprečne mesečne bruto plače na prebivalca med funkcionalnimi regijami, $C D_{P O P(f r)}$ je koeficient odstopanja števila prebivalcev v regiji glede na smernice EU, $w$ je utež za ekonomsko merilo, $1-w$ je utež za merilo velikosti prebivalstva $\mathrm{v}$ regiji in

$$
\begin{aligned}
& C V_{G_{\text {GAR_PC } f r)}}=\frac{\sigma_{G E A R_{-} P C(f r)}}{\mu_{G E A R_{-} P C(f r)}} \\
& C D_{P O P(f r)}=\sqrt{\frac{1}{k} \sum_{i}^{k} D_{i}^{2} / \frac{\left(P O P(r)_{\min }+P O P(r)_{\max }\right)}{2}} \\
& D_{i}^{2}=\left\{\begin{array}{ccc}
P O P(f r)_{i}<P O P(r)_{\min } & \rightarrow & \left(P O P(f r)_{i}-P O P(r)_{\min }\right)^{2} \\
P O P(f r)_{i}>P O P(r)_{\max } & \rightarrow & \left(P O P(f r)_{i}-P O P(r)_{\max }\right)^{2}, \\
\text { sicer } & \rightarrow & 0
\end{array}\right.
\end{aligned}
$$

kjer je $\sigma_{G E A R_{-} P C(f r)}$ standardni odklon povprečne mesečne bruto plače na prebivalca med funkcionalnimi regijami, $\mu_{G E A R_{-} P C(f r)}$ je povprečje povprečnih mesečnih bruto plač na prebivalca v funkcionalnih regijah, $P O P(r)_{\min }$ je najmanjše število prebivalcev v regiji glede na smernice EU in $P O P(r)_{\max }$ je največje število prebivalcev v regiji glede na smernice EU.

V modelu (4) izhajamo iz predpostavke, da si želimo družbenoekonomsko podobno uspešne regije (variabilnost povprečne mesečne bruto plače na prebivalca med funkcionalnimi regijami je minimalna). Model (4) omogoča prilagodljivo analizo družbenoekonomskih in demografskih parametrov (s spreminjanjem uteži $w$ ).

Pregled dejanskih regij na ravneh NUTS 2 in NUTS 3 v državah članicah EU in državah kandidatkah pokaže, da se smernice EU za regije na različnih ravneh NUTS ne upoštevajo dosledno. Zato smo posebej izvedli tudi analizo, pri kateri smo določili število funkcionalnih regij na podlagi zgolj »lokalnega« družbenoekonomskega merila podobne ekonomske razvitosti funkcionalnih regij v državi. 


\section{REZULTATI}

Z uporabo modela odločanja o številu funkcionalnih regij na ravneh NUTS 2 in NUTS 3 se je utež spreminjala od 0 do 1 za 0,1 . Rezultati predlaganega števila funkcionalnih regij na ravneh NUTS 2 in NUTS 3 so v preglednicah 2 in 3. Rezultati kažejo, da ob uporabi šibke ali srednje uteži za variabilnost povprečne mesečne bruto plače na prebivalca $\mathrm{v}$ funkcionalni regiji $(k=2)$ na ravni NUTS 2 prevladujeta dve funkcionalni regiji $(0 \leq w \leq 0,7)$, toda na ravni NUTS 2 so predlagane tudi tri funkcionalne regije $(k=3$, če je $w=0,8)$ v letih 2009 in 2010 ter sedem funkcionalnih regij $(k=7$, če je $w=1)$ v letu 2001. Ob koncu obravnavanega obdobja (2009-2010) se je predlagano število funkcionalnih regij gibalo od $k=2$ (za $0 \leq w \leq 0,7)$ do $k=3$ (za $w=0,8)$ in do $k=4$ (za $w \geq 0,9)$. To pomeni, da merilo EU o velikosti prebivalstva $\mathrm{v}$ regiji izkazuje manj $(k=2)$ večjih funkcionalnih regij, medtem ko »lokalno« ekonomsko merilo »podobnih« regij predvideva število funkcionalnih regij, večje od dveh regij ( $k=4$ ali $k=3$ ), tj. manjših, vendar družbenoekonomsko bolj uravnoteženih funkcionalnih regij na ravni NUTS 2 v Sloveniji; glej preglednico 2.

\begin{tabular}{|c|c|c|c|c|c|c|c|c|c|c|c|}
\hline $\min f(k=\bullet, w=\bullet)$ & \multicolumn{11}{|c|}{$w$} \\
\hline leto & 0 & 0,1 & 0,2 & 0,3 & 0,4 & 0,5 & 0,6 & 0,7 & 0,8 & 0,9 & 1 \\
\hline 2000 & $\begin{array}{c}0,000 \\
(k=2)\end{array}$ & $\begin{array}{c}0,022 \\
(k=2)\end{array}$ & $\begin{array}{c}0,044 \\
(k=2)\end{array}$ & $\begin{array}{c}0,066 \\
(k=2)\end{array}$ & $\begin{array}{c}0,088 \\
(k=2)\end{array}$ & $\begin{array}{c}0,110 \\
(k=2)\end{array}$ & $\begin{array}{c}0,131 \\
(k=2)\end{array}$ & $\begin{array}{c}0,153 \\
(k=2)\end{array}$ & $\begin{array}{c}0,175 \\
(k=2)\end{array}$ & $\begin{array}{c}0,170 \\
(k=5)\end{array}$ & $\begin{array}{c}0,163 \\
(k=5)\end{array}$ \\
\hline 2001 & $\begin{array}{c}0,000 \\
(k=2)\end{array}$ & $\begin{array}{c}0,024 \\
(k=2)\end{array}$ & $\begin{array}{c}0,048 \\
(k=2)\end{array}$ & $\begin{array}{c}0,072 \\
(k=2)\end{array}$ & $\begin{array}{c}0,096 \\
(k=2)\end{array}$ & $\begin{array}{c}0,121 \\
(k=2)\end{array}$ & $\begin{array}{c}0,145 \\
(k=2)\end{array}$ & $\begin{array}{c}0,169 \\
(k=4)\end{array}$ & $\begin{array}{c}0,192 \\
(k=4)\end{array}$ & $\begin{array}{c}0,183 \\
(k=7)\end{array}$ & $\begin{array}{c}0,170 \\
(k=7)\end{array}$ \\
\hline 2004 & $\begin{array}{c}0,000 \\
(k=2)\end{array}$ & $\begin{array}{c}0,025 \\
(k=2)\end{array}$ & $\begin{array}{c}0,050 \\
(k=2)\end{array}$ & $\begin{array}{c}0,075 \\
(k=2)\end{array}$ & $\begin{array}{c}0,100 \\
(k=2)\end{array}$ & $\begin{array}{c}0,125 \\
(k=2)\end{array}$ & $\begin{array}{c}0,150 \\
(k=2)\end{array}$ & $\begin{array}{c}0,175 \\
(k=2)\end{array}$ & $\begin{array}{c}0,192 \\
(k=6)\end{array}$ & $\begin{array}{c}0,181 \\
(k=6)\end{array}$ & $\begin{array}{c}0,171 \\
(k=6)\end{array}$ \\
\hline 2005 & $\begin{array}{l}0,000 \\
(k=2)\end{array}$ & $\begin{array}{c}0,024 \\
(k=2)\end{array}$ & $\begin{array}{c}0,049 \\
(k=2)\end{array}$ & $\begin{array}{c}0,073 \\
(k=2)\end{array}$ & $\begin{array}{c}0,098 \\
(k=2)\end{array}$ & $\begin{array}{c}0,122 \\
(k=2)\end{array}$ & $\begin{array}{c}0,147 \\
(k=2)\end{array}$ & $\begin{array}{c}0,171 \\
(k=2)\end{array}$ & $\begin{array}{c}0,190 \\
(k=6)\end{array}$ & $\begin{array}{c}0,180 \\
(k=6)\end{array}$ & $\begin{array}{c}0,169 \\
(k=6)\end{array}$ \\
\hline 2009 & $\begin{array}{c}0,016 \\
(k=2)\end{array}$ & $\begin{array}{c}0,036 \\
(k=2)\end{array}$ & $\begin{array}{c}0,057 \\
(k=2)\end{array}$ & $\begin{array}{c}0,077 \\
(k=2)\end{array}$ & $\begin{array}{c}0,098 \\
(k=2)\end{array}$ & $\begin{array}{c}0,118 \\
(k=2)\end{array}$ & $\begin{array}{c}0,138 \\
(k=2)\end{array}$ & $\begin{array}{c}0,159 \\
(k=2)\end{array}$ & $\begin{array}{c}0,175 \\
(k=3)\end{array}$ & $\begin{array}{c}0,176 \\
(k=4)\end{array}$ & $\begin{array}{c}0,172 \\
(k=5)\end{array}$ \\
\hline 2010 & $\begin{array}{c}0,016 \\
(k=2)\end{array}$ & $\begin{array}{c}0,036 \\
(k=2)\end{array}$ & $\begin{array}{c}0,056 \\
(k=2)\end{array}$ & $\begin{array}{l}0,075 \\
(k=2)\end{array}$ & $\begin{array}{c}0,095 \\
(k=2)\end{array}$ & $\begin{array}{c}0,115 \\
(k=2)\end{array}$ & $\begin{array}{c}0,135 \\
(k=2)\end{array}$ & $\begin{array}{c}0,155 \\
(k=2)\end{array}$ & $\begin{array}{c}0,172 \\
(k=3)\end{array}$ & $\begin{array}{c}0,172 \\
(k=4)\end{array}$ & $\begin{array}{c}0,168 \\
(k=4)\end{array}$ \\
\hline
\end{tabular}

Preglednica 2: Predlagano število funkcionalnih regij na ravni NUTS $2 v$ Sloveniji glede na model odločanja (4) in različne uteži po obravnavanih letih

\begin{tabular}{|c|c|c|c|c|c|c|c|c|c|c|c|}
\hline $\min f(k=\bullet, w=\bullet$ & \multicolumn{10}{|c|}{$\boldsymbol{0}$} \\
\hline leto & $\mathbf{0}$ & $\mathbf{0 , 1}$ & $\mathbf{0 , 2}$ & $\mathbf{0 , 3}$ & $\mathbf{0 , 4}$ & $\mathbf{0 , 5}$ & $\mathbf{0 , 6}$ & $\mathbf{0 , 7}$ & $\mathbf{0 , 8}$ & $\mathbf{0 , 9}$ & $\mathbf{1}$ \\
\hline \multirow{2}{*}{$\mathbf{2 0 0 0}$} & 0,000 & 0,016 & 0,033 & 0,049 & 0,065 & 0,081 & 0,098 & 0,114 & 0,130 & 0,146 & 0,163 \\
& $(k=5)$ & $(k=5)$ & $(k=5)$ & $(k=5)$ & $(k=5)$ & $(k=5)$ & $(k=5)$ & $(k=5)$ & $(k=5)$ & $(k=5)$ & $(k=5)$ \\
\hline \multirow{2}{*}{$\mathbf{2 0 0 1}$} & 0,000 & 0,018 & 0,036 & 0,055 & 0,073 & 0,091 & 0,109 & 0,127 & 0,145 & 0,160 & 0,170 \\
& $(k=5)$ & $(k=5)$ & $(k=5)$ & $(k=5)$ & $(k=5)$ & $(k=5)$ & $(k=5)$ & $(k=5)$ & $(k=5)$ & $(k=7)$ & $(k=7)$ \\
\hline \multirow{2}{*}{$\mathbf{2 0 0 4}$} & 0,000 & 0,019 & 0,038 & 0,057 & 0,077 & 0,096 & 0,114 & 0,128 & 0,142 & 0,157 & 0,171 \\
& $(k=5)$ & $(k=5)$ & $(k=5)$ & $(k=5)$ & $(k=5)$ & $(k=5)$ & $(k=6)$ & $(k=6)$ & $(k=6)$ & $(k=6)$ & $(k=6)$ \\
\hline \multirow{2}{*}{$\mathbf{2 0 0 5}$} & 0,000 & 0,019 & 0,038 & 0,057 & 0,076 & 0,095 & 0,112 & 0,127 & 0,141 & 0,155 & 0,169 \\
& $(k=5)$ & $(k=5)$ & $(k=5)$ & $(k=5)$ & $(k=5)$ & $(k=5)$ & $(k=6)$ & $(k=6)$ & $(k=6)$ & $(k=6)$ & $(k=6)$ \\
\hline \multirow{2}{*}{$\mathbf{2 0 0 9}$} & 0,020 & 0,037 & 0,054 & 0,071 & 0,088 & 0,104 & 0,121 & 0,138 & 0,155 & 0,168 & 0,172 \\
& $(k=5)$ & $(k=5)$ & $(k=5)$ & $(k=5)$ & $(k=5)$ & $(k=5)$ & $(k=5)$ & $(k=5)$ & $(k=5)$ & $(k=7)$ & $(k=4)$ \\
\hline \multirow{2}{*}{$\mathbf{2 0 1 0}$} & 0,026 & 0,042 & 0,057 & 0,073 & 0,089 & 0,105 & 0,121 & 0,137 & 0,153 & 0,167 & 0,168 \\
& $(k=5)$ & $(k=5)$ & $(k=5)$ & $(k=5)$ & $(k=5)$ & $(k=5)$ & $(k=5)$ & $(k=5)$ & $(k=5)$ & $(k=7)$ & $(k=4)$ \\
\hline
\end{tabular}

Preglednica 3: Predlagano število funkcionalnih regij na ravni NUTS $3 v$ Sloveniji glede na model odločanja (4) in različne uteži po obravnavanih letih 
Glede na model (4) je prevladujoče število funkcionalnih regij na ravni NUTS 3 pet funkcionalnih regij v Sloveniji ( $k=5$ za $0 \leq w \leq 0,8)$ za leta 2000, 2001, 2009 in 2010, predlagano največje število funkcionalnih regij pa je sedem $(k=7)$ za leto 2001 (za $w \geq 0,9)$ in tudi za leti 2009 in 2010 (za $w=0,9$ ); glej preglednico 3.

Rezultati modela odločanja (4) kažejo, da (velik) poudarek na smernicah EU glede števila prebivalcev v NUTS-regijah vodi k sistemom manjšega števila funkcionalnih regij, če pa si želimo družbenoekonomsko podobne regije (ustreznejša porazdelitev povprečne mesečne bruto plače na prebivalca med funkcionalnimi regijami), potem so ustreznejši sistemi večjega števila manjših funkcionalnih regij v Sloveniji. Iz preglednice 3 vidimo tudi, da je gospodarski vzpon v letih 2004 in 2005 pri večjem poudarjanju družbenoekonomske enakosti zahteval več funkcionalnih regij, ko pa se je gospodarstvo »skrčilo«, so se tudi zahteve po številu regij vrnile na stare tire: večje regije lažje prenesejo gospodarske pretrese. Pregled dejanskih regij na ravneh NUTS 2 in NUTS $3 \mathrm{v}$ državah članicah EU in državah kandidatkah potrjuje dejstvo, da se smernice EU za regije na različnih ravneh NUTS ne upoštevajo dosledno. Tako je bila na primer najmanjša regija na ravni NUTS 2 v EU Aland (FI20) s povprečnim številom prebivalcev 26.500 v obdobju 2000-2009, največja regija na ravni NUTS 2 pa je bila Ile-de-France (FR10) s povprečno več kot 11 milijoni prebivalcev v obdobju 2000-2009 (glej sliko 2). Na ravni NUTS 3 je bila - poleg majhnega španskega otoka v Atlantiku (El Hierro, ES703) in švicarske regije Appenzell Innerrhoden (CH054) - najmanjša regija v EU Evrytania (GR243) s povprečnim številom prebivalcev 19.500, medtem ko je bila največja regija - poleg Istanbula (TR100) v kandidatki za priključitev - Madrid (ES300) s približno 5,8 milijona prebivalcev v povprečju v obdobju 2000-2009 (glej sliko 3).

Na ravni NUTS 2 v Sloveniji je imela Vzhodna Slovenija (01) pribl. 1,1 milijona prebivalcev in Zahodna Slovenija (02) v povprečju pribl. 925.520 prebivalcev v obdobju 2000-2009. Na ravni NUTS 3 v Sloveniji je bila najmanjša regija Zasavska regija (05) z zgolj pribl. 45.540 prebivalcev, medtem ko je bila Osrednjeslovenska regija (08) največja regija na ravni NUTS 3 v Sloveniji s pribl. 501.280 prebivalcev v povprečju v obdobju 2000-2009 (glej preglednico 4).

\begin{tabular}{|l|r|r|r|r|}
\hline & \multicolumn{2}{|c|}{ NUTS 2 } & \multicolumn{2}{c|}{ NUTS 3 } \\
\hline & \multicolumn{1}{|c|}{ najmanjše } & \multicolumn{1}{c|}{ največje } & \multicolumn{1}{c|}{ najmanjše } & \multicolumn{1}{c|}{ največje } \\
\hline Slovenija & pribl. 925.520 & pribl. 1.080 .210 & pribl. 45.540 & pribl. 501.280 \\
\hline EU & pribl. 26.500 & pribl.11.390.600 & pribl. 19.500 & pribl. 5.803.570 \\
\hline Eurostat & 800.000 & 3.000 .000 & 150.000 & 800.000 \\
\hline
\end{tabular}

Preglednica 4: Najmanjše in največje število prebivalcev v regijah na ravneh NUTS 2 in NUTS 3 v EU in Sloveniji v povprečju v obdobju 2000-2009 in smernice za ustanovitev regij na ravneh NUTS 2 in NUTS 3 (Eurostat, 2011; ES, 2003)

Sliki 2 in 3 prikazujeta povprečno število prebivalcev v obdobju 2000-2009 v regijah na ravneh NUTS 2 in NUTS 3 v državah članicah EU in državah kandidatkah. Razvidno je, da so v EU na ravneh NUTS 2 in NUTS 3 nekatere regije manjše, druge pa večje po površini kot v Sloveniji ter in da imajo nekatere manj, druge pa več prebivalcev. Dejstvo je, da bi bilo število regij v Sloveniji na ravneh NUTS 2 in NUTS 3 lahko nižje ali višje, kot je. Zaradi tega smo v raziskavi preverili tudi samo ekonomsko merilo, tj. koeficient variacije povprečne mesečne bruto plače na prebivalca 
med funkcionalnimi regijami, in iskali lokalne minimume obravnavanega ekonomskega parametra za sisteme z od 2 do 30 funkcionalnimi regijami v Sloveniji. Lokalni minimumi analiziranega parametra določajo sisteme ekonomsko podobnih funkcionalnih regij. Slike od 4 do 6 kažejo koeficient variacije povprečne mesečne bruto plače na prebivalca med funkcionalnimi regijami glede na 29 sistemov z od 2 do 30 funkcionalnimi regijami v Sloveniji v letih 2000-2001, 2004-2005 in 2009-2010. Na slikah so lokalni minimumi označeni s črnim krogom ali elipso, sive elipse pa označujejo sisteme funkcionalnih regij, ki so blizu lokalnim minimumom in bi bili prav tako lahko "primerni« sistemi funkcionalnih regij (z majhno variabilnostjo analiziranih ekonomskih parametrov med funkcionalnimi regijami).

Ekonomsko najbolj podobne funkcionalne regije v letih 2000 in 2001 so bile funkcionalne regije $\mathrm{v}$ sistemih s po 5, 14, 19, 21 in 25 funkcionalnimi regijami v državi. V bližini lokalnih minimumov je bilo več sistemov funkcionalnih regij s podobno homogenostjo med regijami; to so bili sistemi s po $4-6,12-15,17-19,21-22$ in 24-26 funkcionalnimi regijami. Leta 2004 in 2005 , ko se je Slovenija pridružila EU, so se spremenili tudi medobčinski tokovi migracij v Sloveniji, ki so opredelili funkcionalne regije - predvsem za sisteme s po 9, 18 in 18 funkcionalnimi regijami. Najmanjša variabilnost povprečne mesečne bruto plače na prebivalca med funkcionalnimi regijami je bila za sisteme s po 5-7 funkcionalnimi regijami (z lokalnim minimumom 6), 12-15 funkcionalnimi regijami (z lokalnim minimumom 14) ter v sistemih s po 22-25 funkcionalnimi regijami (z lokalnim minimumom 22). Za zadnje obravnavano obdobje 2009-2010 so, glede na analizirani ekonomski parameter, najbolj stabilni sistemi funkcionalnih regij s po 3-4 (z lokalnim minimumom 4), 7, 12-14 (z lokalnim minimumom 14) funkcionalnimi regijami in sistem z 20 oziroma 22 funkcionalnimi regijami v državi.

Po združevanju rezultatov (krivulje koeficienta variacije povprečne mesečne bruto plače na prebivalca med funkcionalnimi regijami) za vsa tri obravnavana obdobja na istem grafu (glej sliko 7) smo ugotovili, kateri sistemi funkcionalnih regij so bili najbolj stabilni v celotnem desetletnem obdobju; to so bili sistemi s po 7 in 12-14 funkcionalnimi regijami (z lokalnim minimumom 14), za zadnja obravnavana obdobja pa tudi sistemi s po 3-4 funkcionalnimi regijami (z lokalnim minimumom 4), 19-20 funkcionalnimi regijami (z lokalnim minimumom 20) in sistem z 22 funkcionalnimi regijami v Sloveniji.

S slike 7 je razvidno, da se sistem s 7 funkcionalnimi regijami v obdobju 2000-2010 ni bistveno spremenil - dejansko se je spremenil le med letoma 2000 in 2001, medtem ko je med letoma 2001 in 2010 ostal enak. To nas je privedlo do ugotovitve, da je sistem s 7 funkcionalnimi regijami najbolj stabilen sistem funkcionalnih regij v Sloveniji. Sliki 16 in 17 prikazujeta sistem s 7 funkcionalnimi regijami v Sloveniji v letih 2001 in 2001-2010.

Slike od 8 do 17 prikazujejo sisteme funkcionalnih regij, modelirane $\mathrm{z}$ metodo Intramax; prikazani so sistemi z istim številom funkcionalnih regij, kot je število regij na ravneh NUTS 2 in NUTS 3 (slike 8, 9, 12 in 13), sistemi funkcionalnih regij z lokalnim minimumom na ravneh NUTS 2 in NUTS 3 (slike 10,11, 14 in 15) in nazadnje še sistem s 7 funkcionalnimi regijami, ki se je pokazal kot najbolj stabilen sistem funkcionalnih regij v letu 2000 oziroma v obdobju 2001-2010 (sliki 16 in 17). 


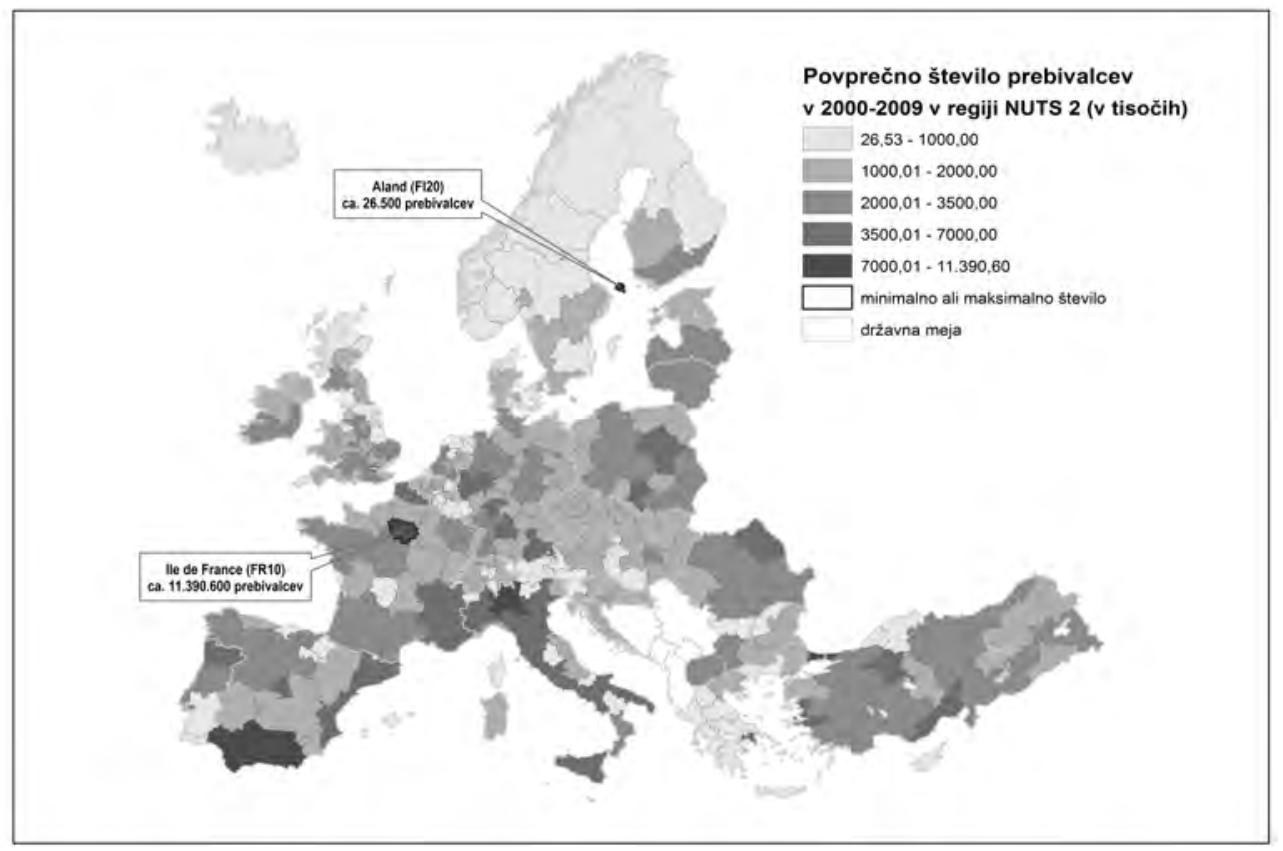

Slika 2: Povprečno število prebivalcev v regijah na ravni NUTS $2 v$ državah članicah EU in državah kandidatkah v obdobju 2000-2009 (v tisočih)

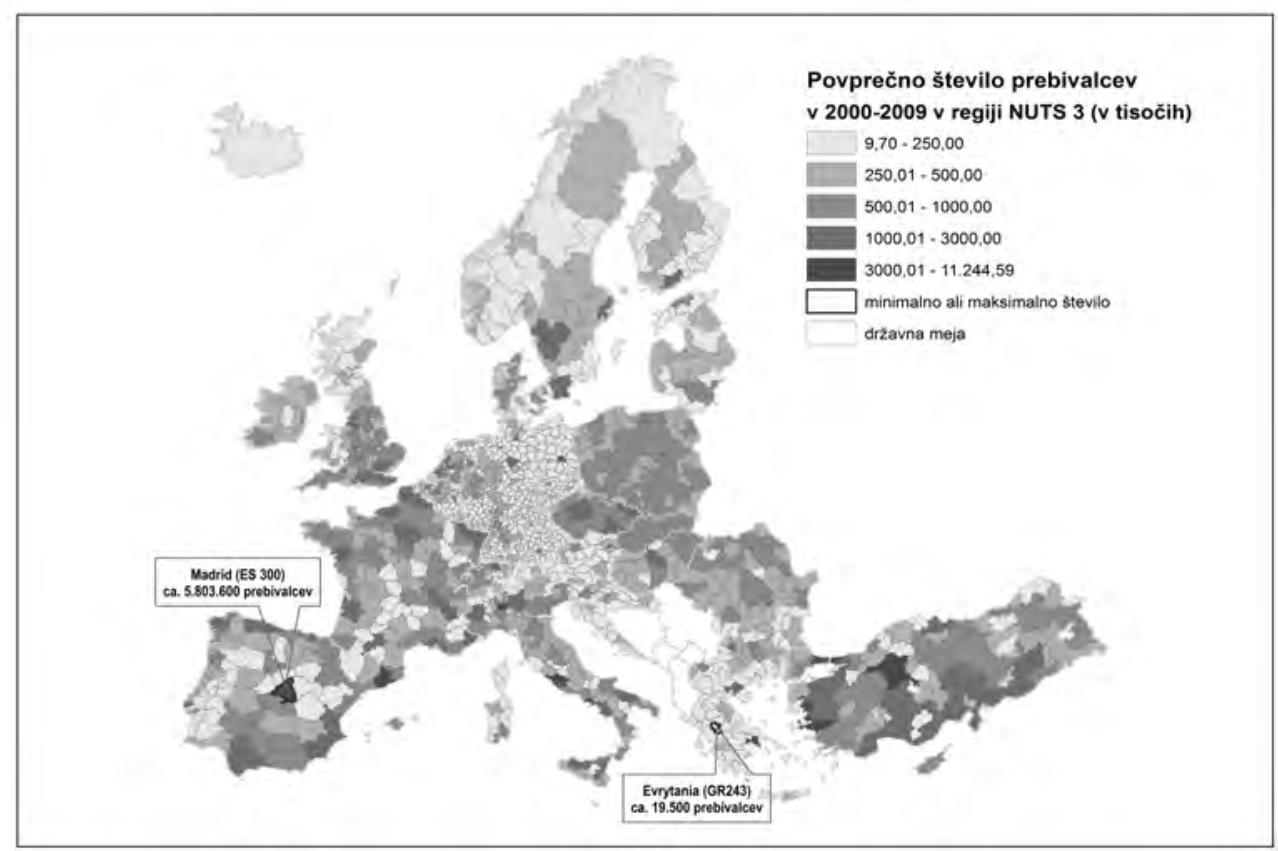

Slika 3: Povprečno število prebivalcev $v$ regijah na ravni NUTS $3 v$ državah članicah EU in državah kandidatkah v obdobju 2000-2009 (v tisočih) 


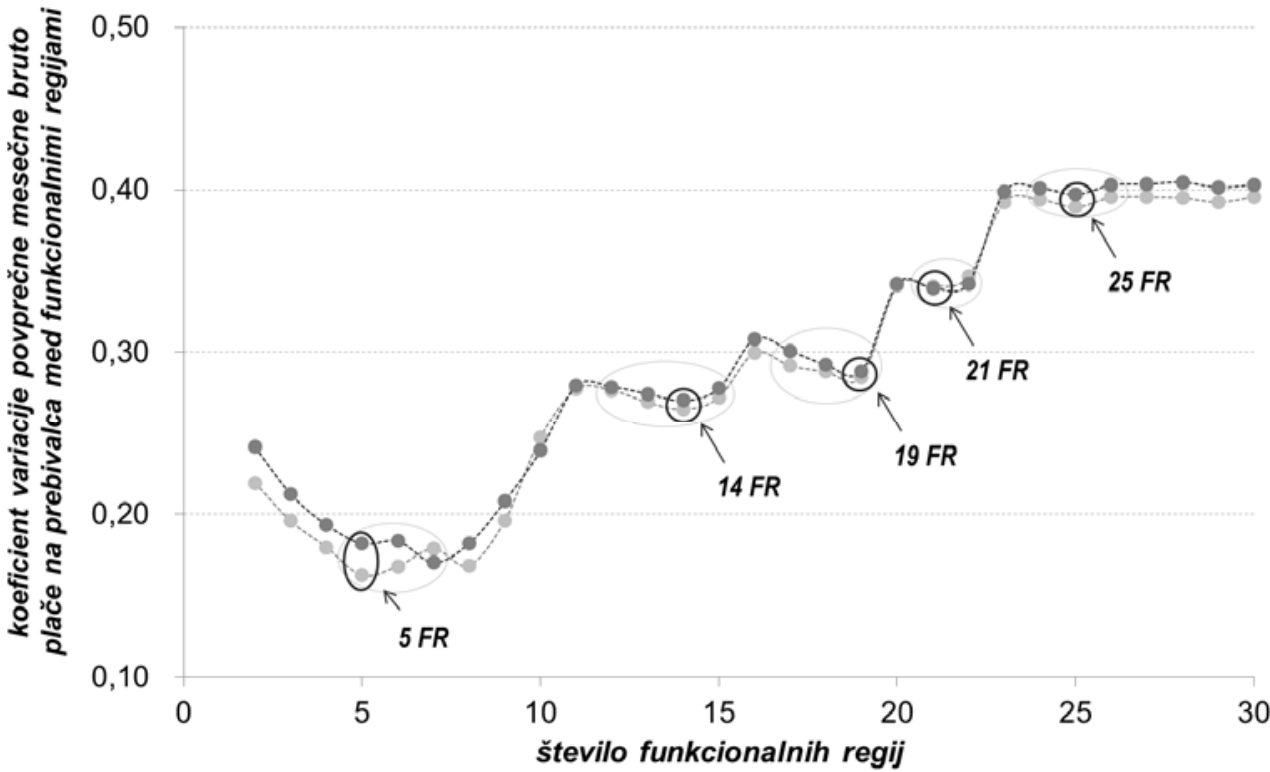

$\cdots \cdot \cdots$ leto $2000 \cdots \cdot \cdots$ leto 2001

Slika 4: Koeficient variacije povprečne mesečne bruto plače na prebivalca med funkcionalnimi regijami po sistemu funkcionalnih regij v Sloveniji v letih 2000 in 2001

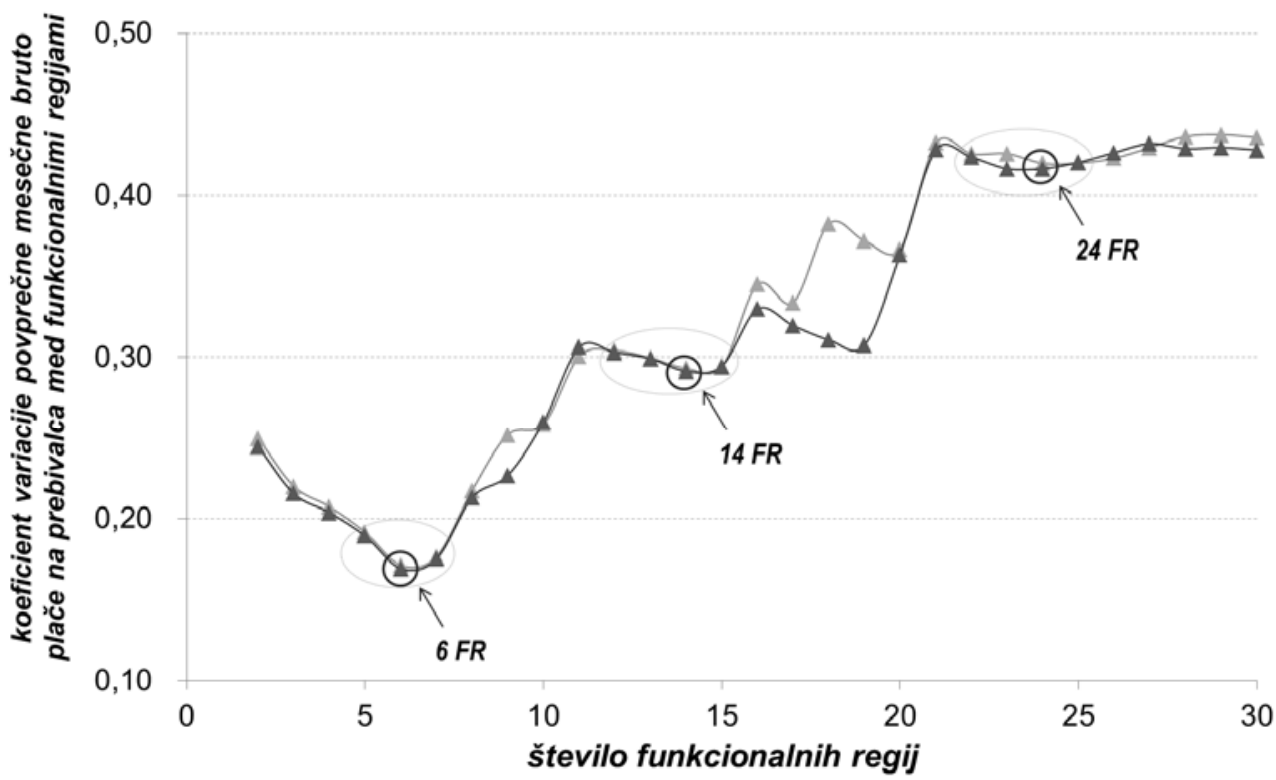

\leto 2004 \leto 2005

Slika 5: Koeficient variacije povprečne mesečne bruto plače na prebivalca med funkcionalnimi regijami po sistemu funkcionalnih regij v Sloveniji v letih 2004 in 2005 


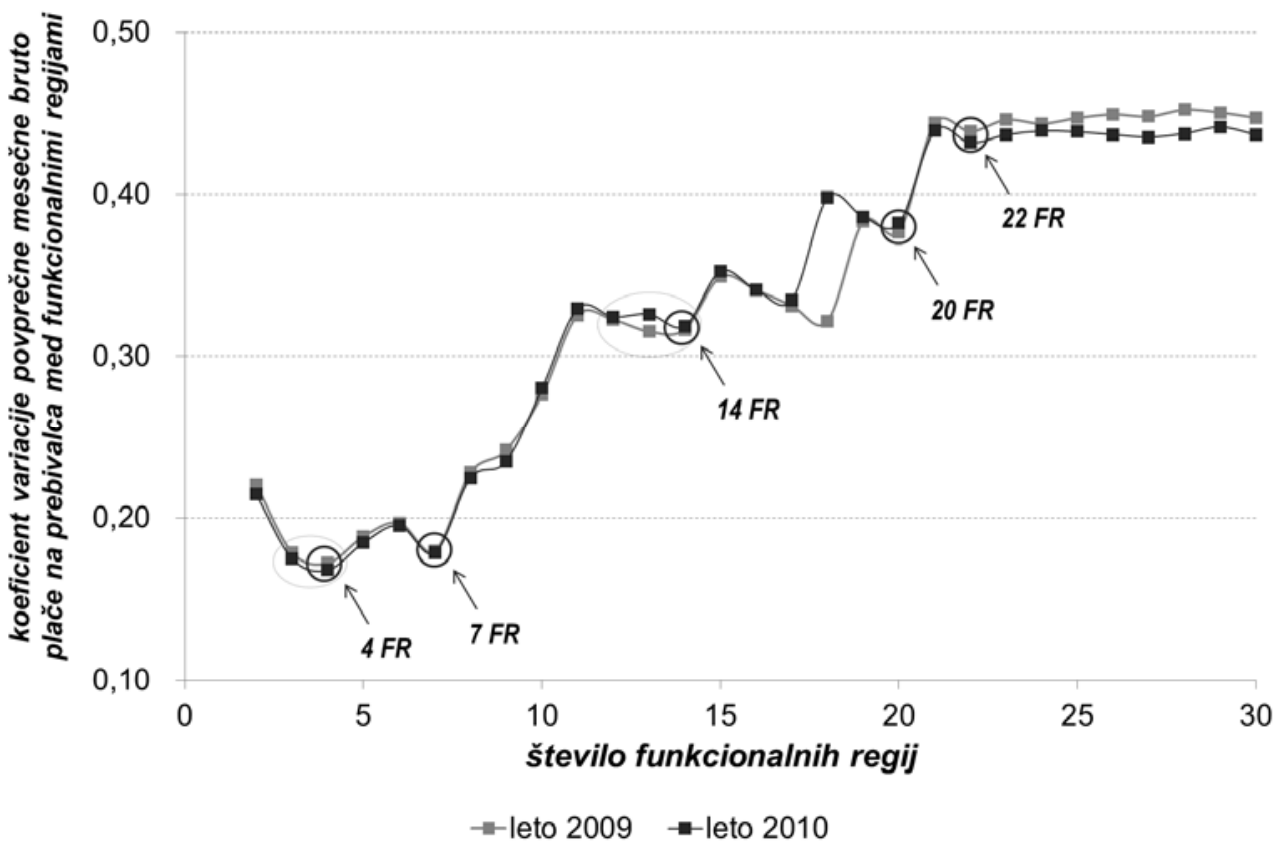

Slika 6: Koeficient variacije povprečne mesečne bruto plače na prebivalca med funkcionalnimi regijami po sistemih funkcionalnih regij v Sloveniji v letih 2009 in 2010

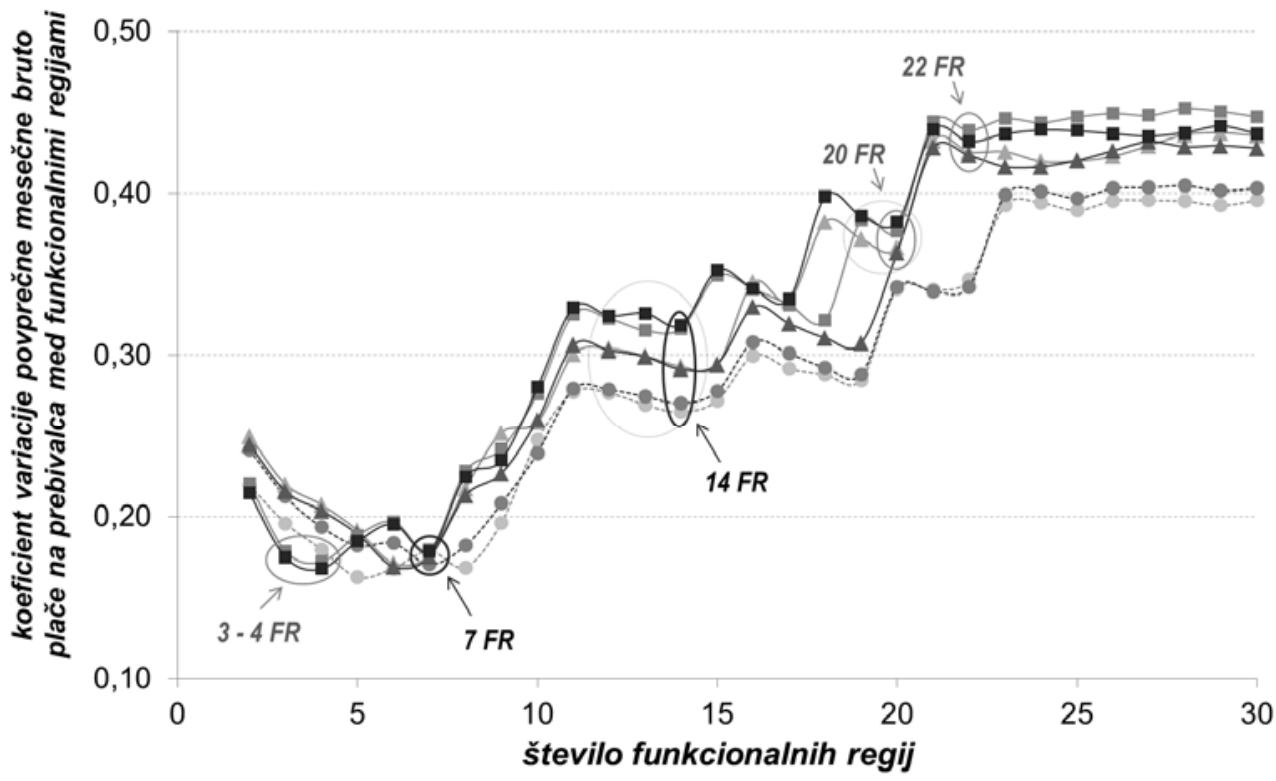

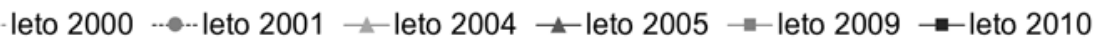

Slika 7: Koeficient variacije povprečne mesečne bruto plače na prebivalca med funkcionalnimi regijami po sistemih funkcionalnih regij v Sloveniji v letih 2000-2001, 2004-2005 in 2009-2010 


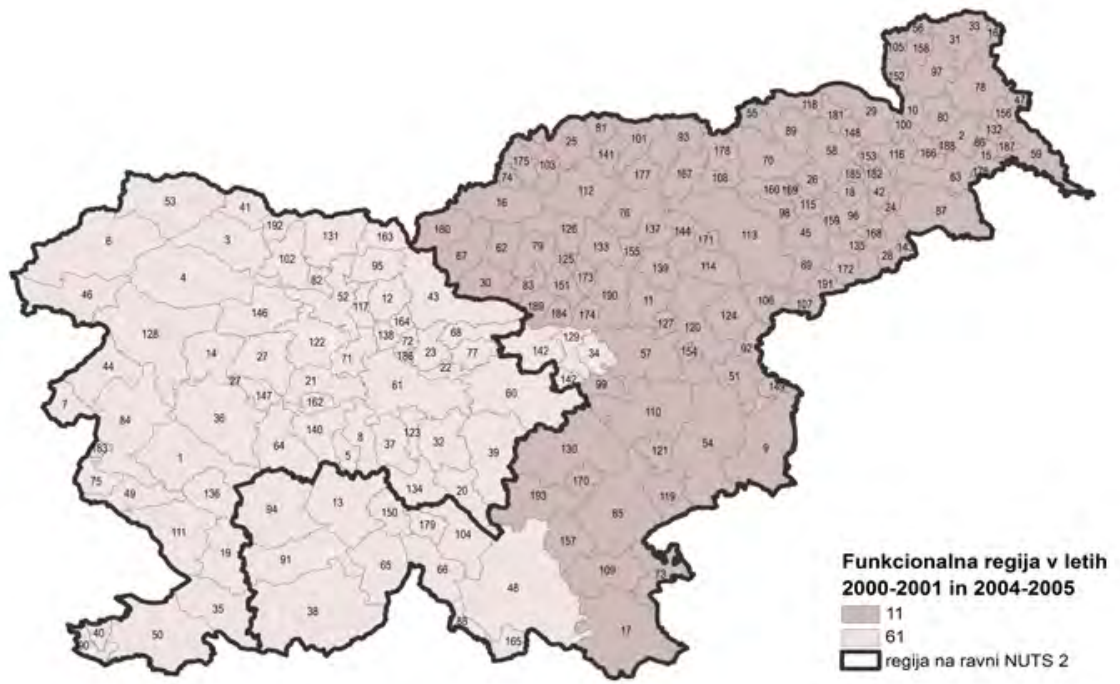

Slika 8: Dve funkcionalni regiji v obdobjih 2000-2001, 2004-2005 in dve regiji na ravni NUTS 2 v Sloveniji (šifrant občin je $v$ prilogi 1)

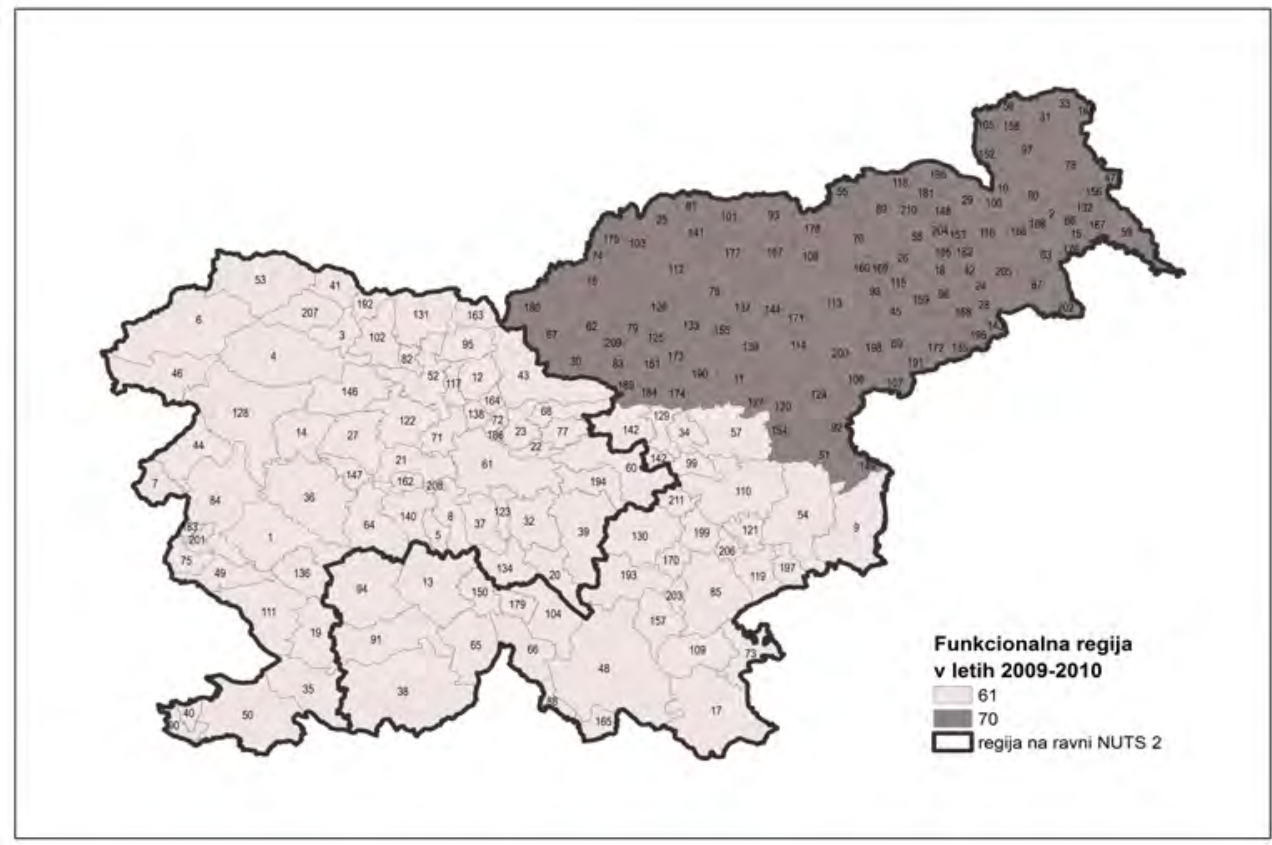

Slika 9: Dve funkcionalni regiji v obdobju 2009-2010 in dve regiji na ravni NUTS 2 v Sloveniji (šifrant občin je v prilogi 1) 


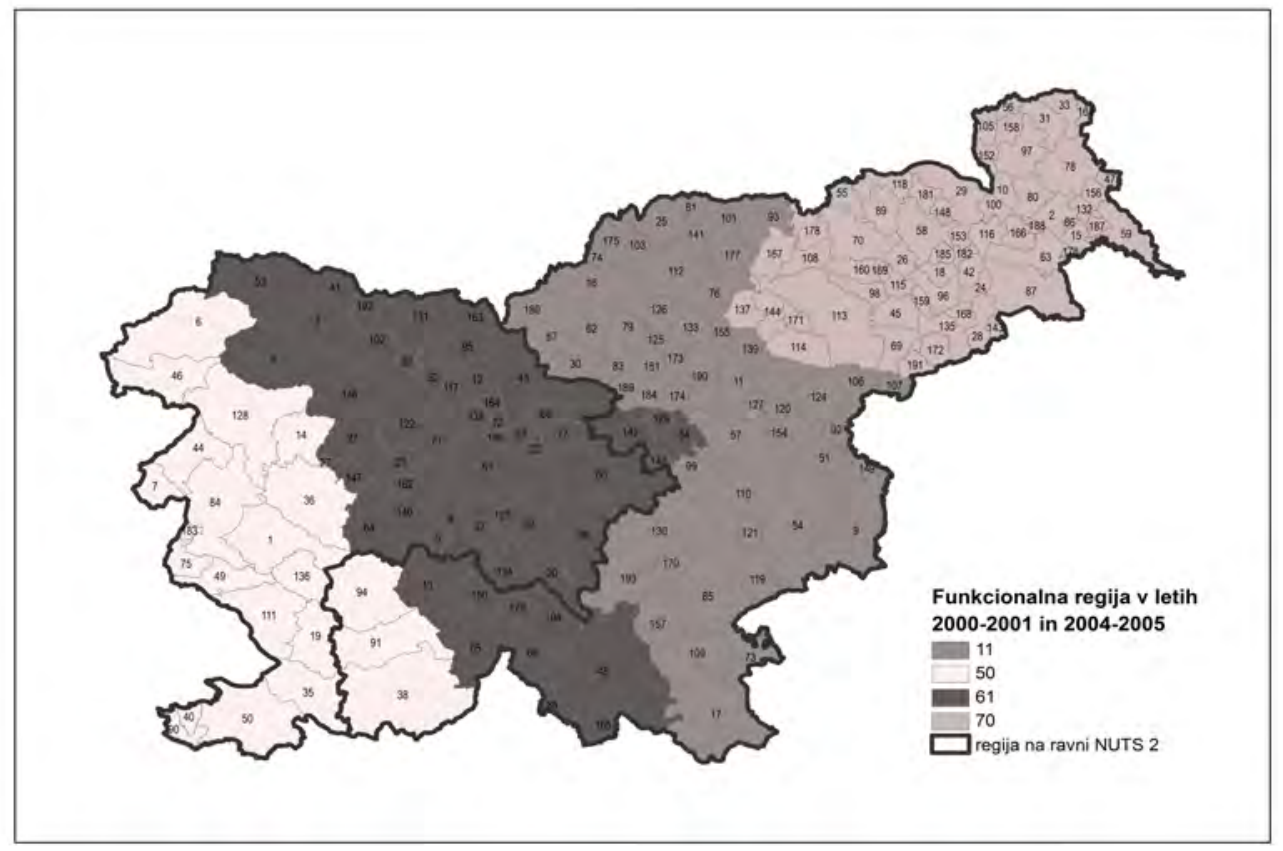

Slika 10: Štiri funkcionalne regije $v$ obdobjih 2000-2001, 2004-2005 in dve regiji na ravni NUTS $2 v$ Sloveniji (šifrant občin je $v$ prilogi 1)

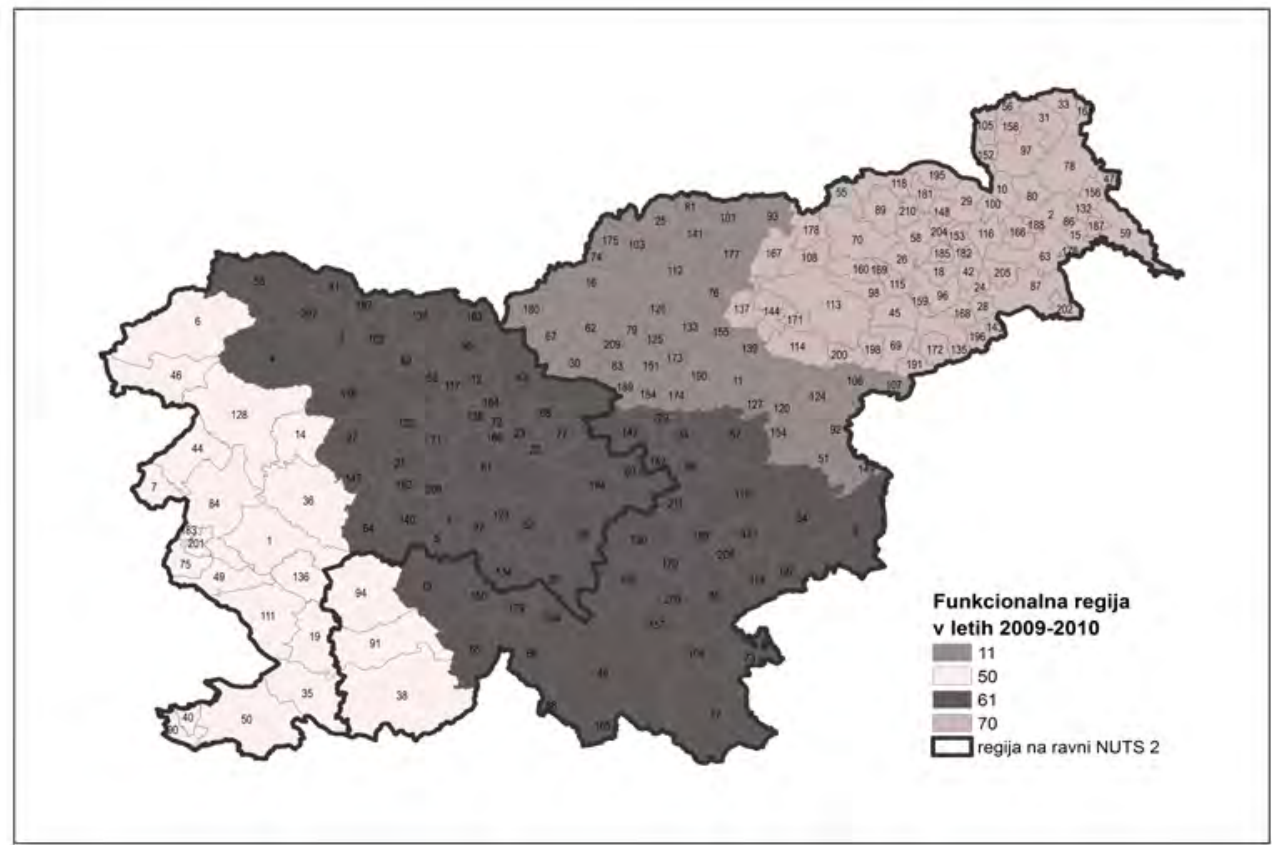

Slika 11: Štiri funkcionalne regije v obdobju 2009-2010 in dve regiji na ravni NUTS 2 v Sloveniji (šifrant občin je $v$ prilogi 1) 


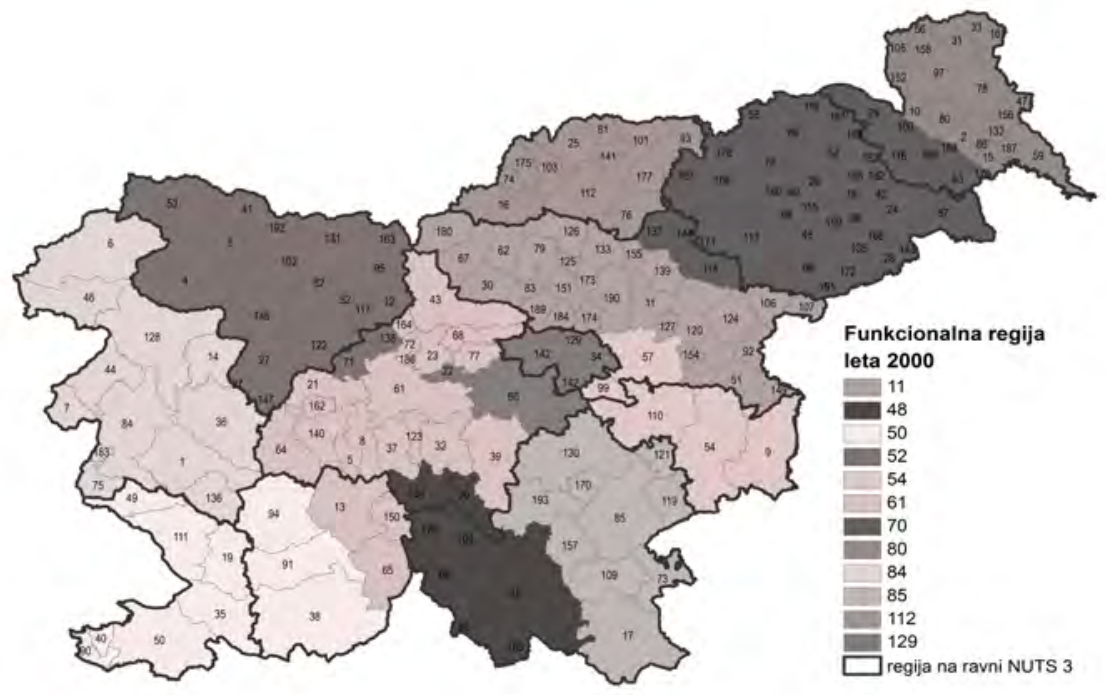

Slika 12: Dvanajst funkcionalnih regij v letu 2000 in dvanajst regij na ravni NUTS 3 v Sloveniji (šifrant občin je v prilogi 1)

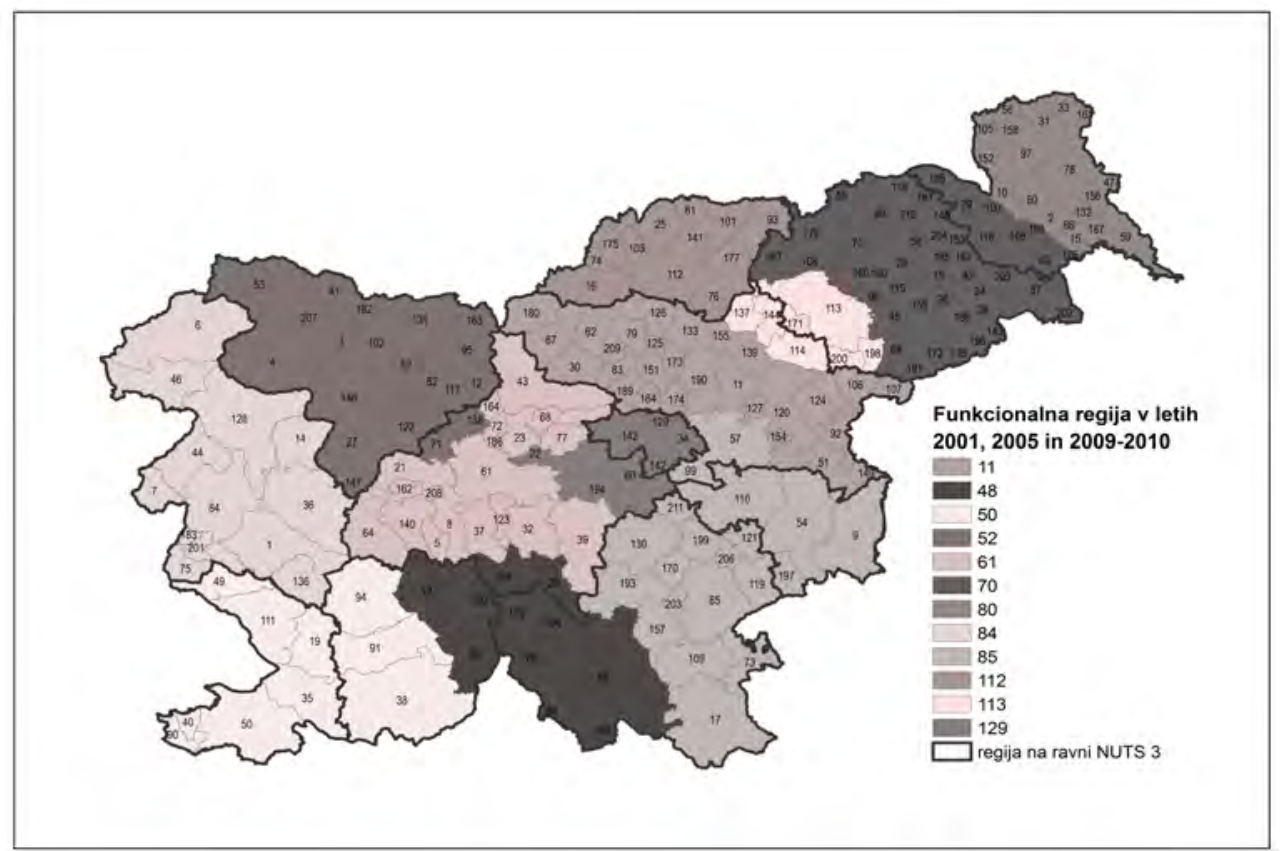

Slika 13: Dvanajst funkcionalnih regij v letih 2001, 2005, 2009-2010 in dvanajst regij na ravni NUTS 3 v Sloveniji (šifrant občin je $v$ prilogi 1) 


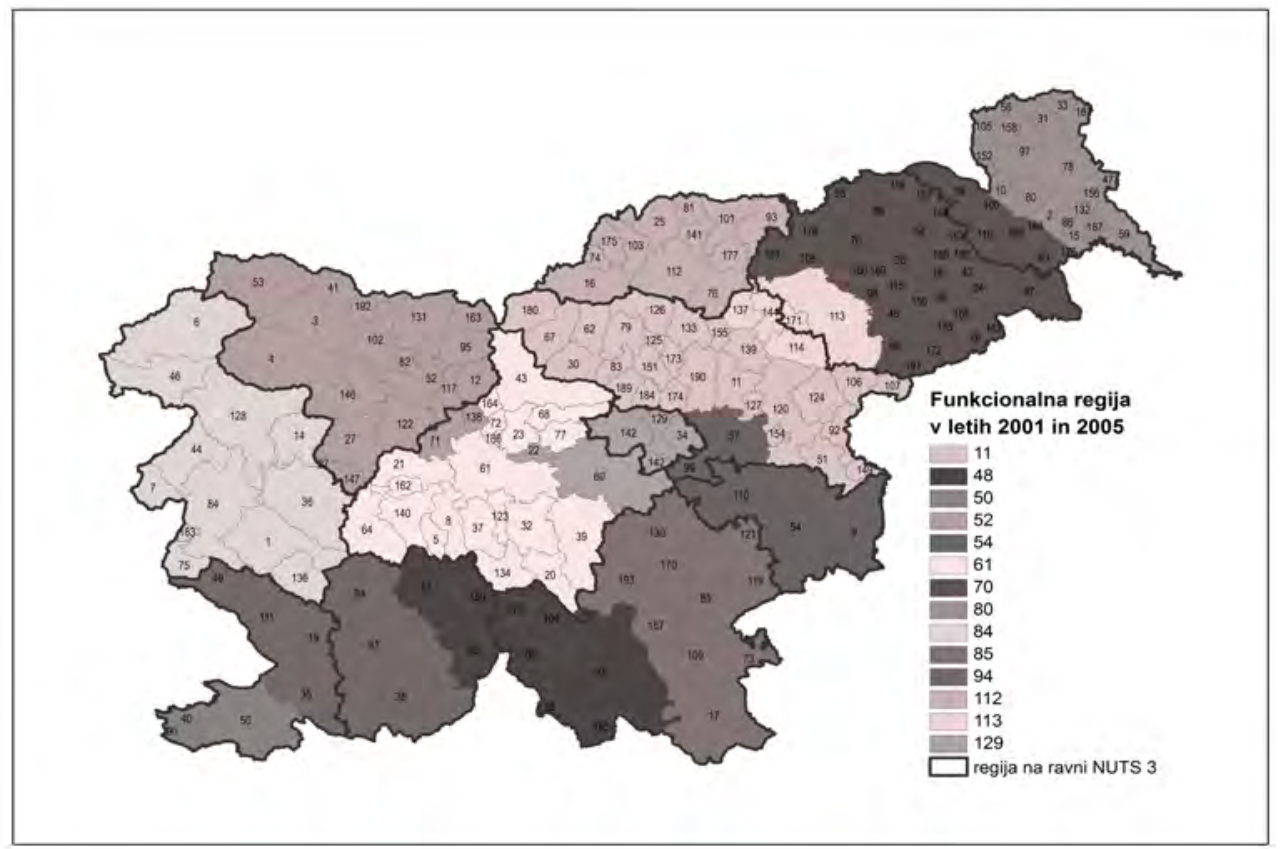

Slika 14: Štirinajst funkcionalnih regij v letih 2001 in 2005 in dvanajst regij na ravni NUTS 3 v Sloveniji (šifrant občin je v prilogi 1)

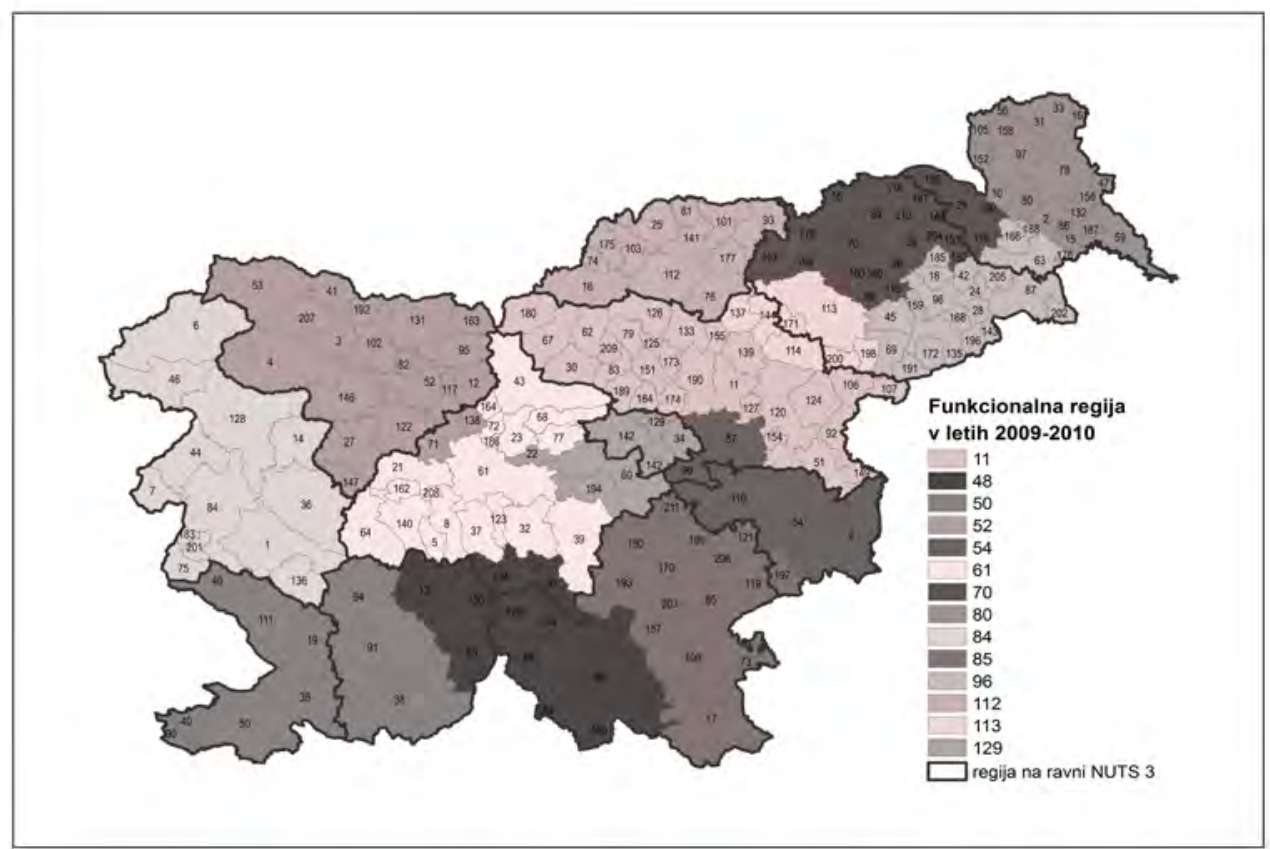

Slika 15: Štirinajst funkcionalnih regij v obdobju 2009-2010 in dvanajst regij na ravni NUTS 3 v Sloveniji (šifrant občin je v prilogi 1) 


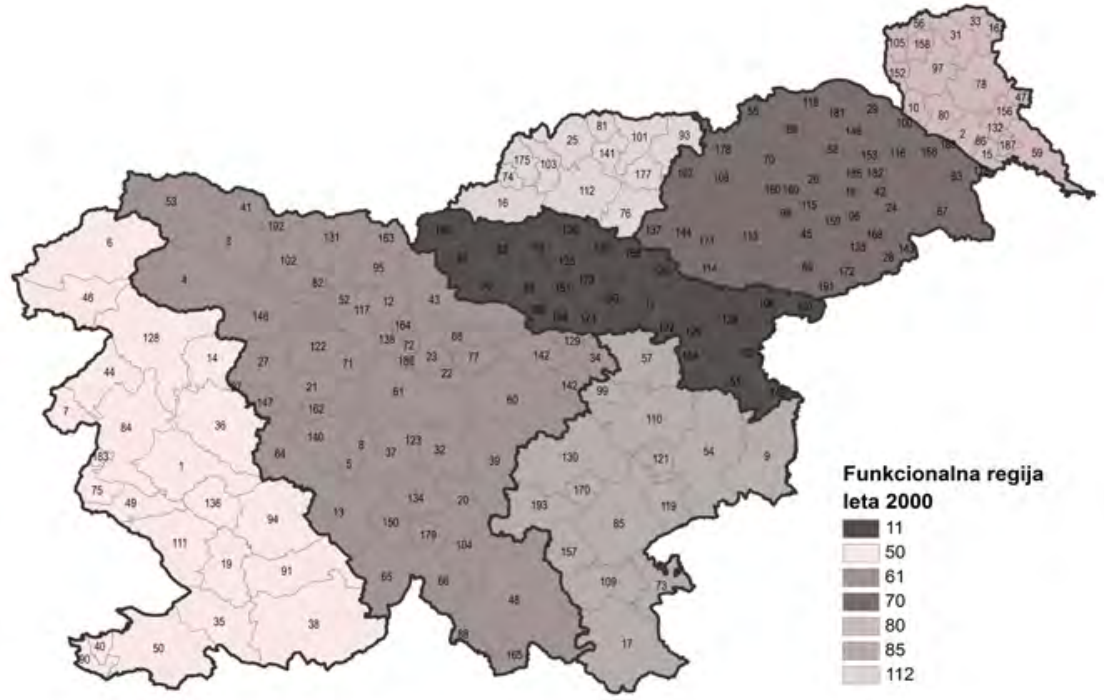

Slika 16: Sedem funkcionalnih regij v Sloveniji v letu 2000 (šifrant občin je v prilogi 1)

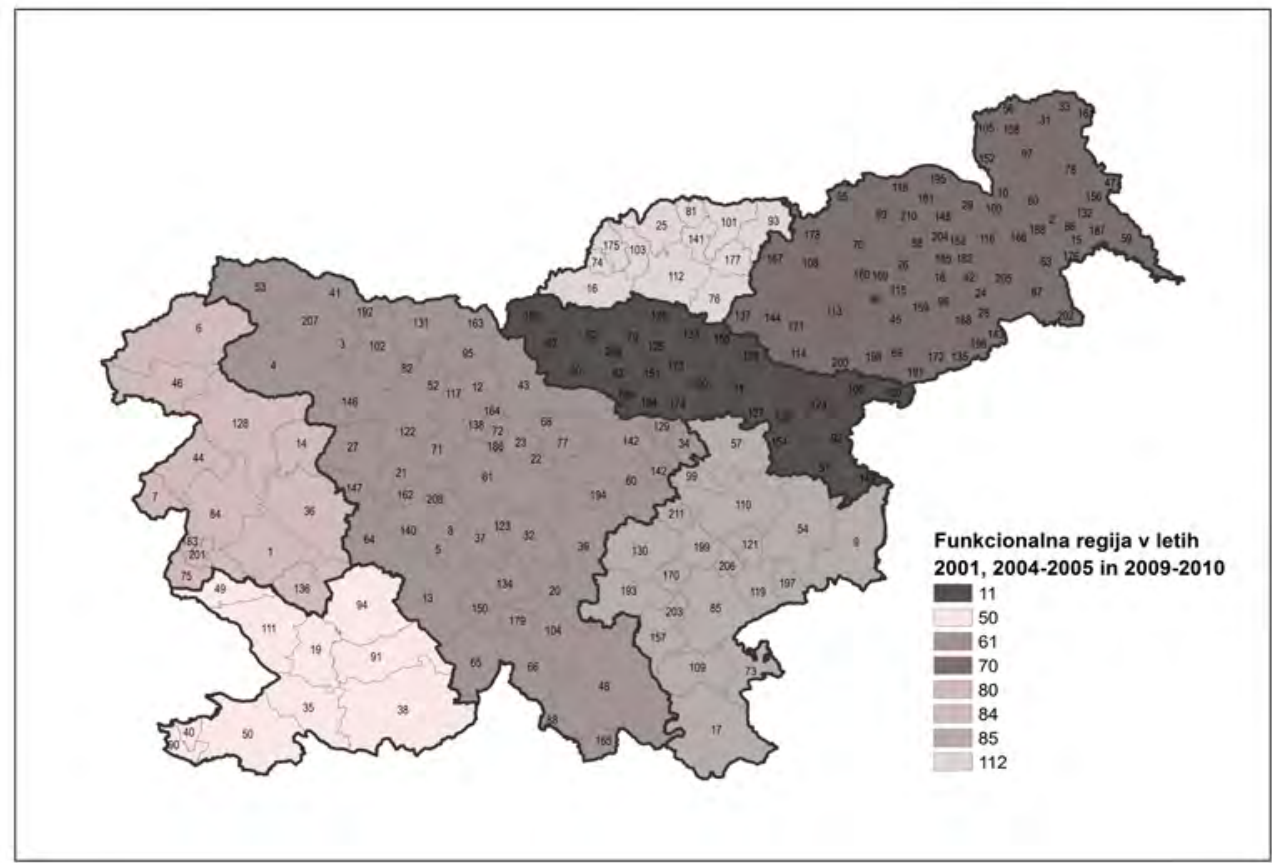

Slika 17: Sedem funkcionalnih regij v Sloveniji v letih 2001, 2004-2005 in 2009-2010 (šifrant občin je v prilogi 1) 


\section{SKLEP}

V prispevku smo predstaviti metodo za odločanje o številu funkcionalnih regij v državi. Izvedba algoritmov za razmejitev funkcionalnih regij v programski opremi omogoča hitro modeliranje več različnih sistemov funkcionalnih regij. Ob tem ne moremo prezreti vprašanja o »pravem « številu funkcionalnih regij. V predlaganem modelu za odločanje o številu funkcionalnih regij sta upoštevani dve merili: družbenoekonomsko merilo povprečne mesečne bruto plače na prebivalca v funkcionalni regiji, ki lahko zagotavlja bolj izenačeno kakovost življenja med regijami, in merilo smernic EU glede števila prebivalcev v regiji. Model bi lahko izboljšali ob upoštevanju drugih, bolj holističnih ekonomskih parametrov (npr. BDP), z vključitvijo dodatnega funkcionalnega merila $\mathrm{v}$ postopek odločanja (npr. potni stroški $\mathrm{v}$ funkcionalni regiji kot celoti ali $\mathrm{v}$ regijsko središče kot prihodnje administrativno središče) ali z združevanjem gravitacijskih pristopov v metodah razmejitve funkcionalnih regij, kar v bližnji prihodnosti nameravamo preučiti tudi sami.

Ob uporabi tukaj predlaganega modela za primer Slovenije smo funkcionalne regije razmejili $\mathrm{z}$ uporabo metode Intramax in pri tem upoštevali tokove delavcev vozačev med občinami $\mathrm{v}$ Sloveniji v treh obdobjih: 2000-2001, 2004-2005 in 2009-2010. Rezultati modela kažejo, da smernice EU glede števila prebivalcev v NUTS-regijah določajo sisteme manjšega števila večjih funkcionalnih regij v državi, medtem ko »lokalno« ekonomsko merilo o družbenoekonomsko uravnoteženo razvitih regijah določa sisteme $\mathrm{z}$ višjim številom manjših funkcionalnih regij - to še posebej velja za obdobje gospodarske konjunkture.

Rezultati modeliranja funkcionalnih regij Slovenije tudi pokažejo, da le-te večinoma niso skladne z upravno (nominalno) določenimi regijami na različnih ravneh analize. Večja nezdružljivost se pokaže ne zgolj pri manjšem številu funkcionalnih regij (npr. na ravni NUTS 2), temveč tudi pri večjem številu funkcionalnih regij v Sloveniji (npr. na ravni NUTS 3). To kaže na potrebo po bolj podrobni obravnavi neskladja med administrativnimi in funkcionalnimi regijami v Sloveniji. Morebitne nove administrativne regije v Sloveniji bi lahko razmejili z nadaljnjim preučevanjem medsebojnih odnosov, z gravitacijsko analizo trgov dela, območij izobraževanja in gravitacijskih območij ponudbe in povpraševanja po blagu in storitvah, in to ne le za zadnje obdobje, temveč tudi s preučevanjem dinamike. Reorganizacija strukture lokalne (in tudi regionalne) uprave po pristopu funkcionalne členitve regij je težka in draga. Če želimo, da oblikovalci različnih politik in odločevalci prepoznajo funkcionalno členjene regije kot pomembne, morajo le-te ponujati znatno višje koristi v primerjavi $\mathrm{z}$ administrativno (nominalno) opredeljenimi regijami (Cörvers in sod., 2009).

Zapletena teritorialna organizacija večine političnih in upravnih sistemov v državah članicah EU izhaja iz zgodovine in tradicije ter tudi iz močne politične volje. Večina pokrajinskih in okrožnih upravnih struktur je podedovana iz preteklosti in v njih se odražajo upravne entitete različnih družbenih sistemov. Iz različnih razlogov je pomembno, da se v novih državah članicah EU, v katerih ni vmesne ravni teritorialne upravne organizacije med državno in občinsko ravnijo, vzpostavi srednja raven regionalne uprave (Schrerrer, 2006; Drobne in sod., 2009a, 2009b). V zadnjih dveh desetletjih v Sloveniji poteka razprava o ustanovitvi administrativnih regij (pokrajin) kot vmesne ravni teritorialne organizacije v Sloveniji. Glavni cilj take (administrativne) 
reorganizacije Slovenije je decentralizacija državnih funkcij in prenos pomembnega dela javnih zadev z državne na regionalno (pokrajinsko) raven. Omeniti je treba še dva pomembna cilja regionalizacije: uravnotežen regionalni razvoj (policentrični razvoj države) in mednarodno sodelovanje. Zadnja študija ocene stanja v prostoru Slovenije, ki jo izvaja Organizacija za gospodarsko sodelovanje in razvoj (OECD, 2011), prinaša ugotovitev, da »mora Slovenija okrepiti obstoječe regionalne strukture ${ }^{3}$ in na srednji rok razmisliti o zmanjševanju njihovega števila, saj se zdi to bolj smotrno kot vzpostavitev nove regionalne administrativne ravni«. Tukaj predlagana metoda za opredelitev števila funkcionalno aktivnih regij lahko pomaga nosilcem odločanja pri odločitvi o »primernem « številu regij v Sloveniji, tj. izbrati sistem sedmih funkcionalnih regij, ki se je v zadnjem desetletju izkazal za najbolj stabilnega (glej sliko 17).

\section{Literatura in viri:}

Andersen, A. K. (2002). Are commuting areas relevant for the delimitation of administrative regions in Denmark?, Regional Studies, 36, 833-844.

Bajt, L. (2010). Primer informacijskega sistema za modeliranje funkcionalnih regij v Sloveniji. Magistrsko delo. Univerza v Ljubljani, Ekonomska fakulteta. Ljubljana.

Ball, R. M. (1980). The use and definition of Travel-to-Work areas in Great Britain: Some problems. Regional Studies, 14(2), 125-139.

Bond, S., Coombes, M. (2007). 2001-based Travel-To-Work Areas Methodology. London. Office for National Statistics.

Brown, L. A., Holmes, J. (1971). The delimitation of functional regions, nodal regions, and hierarchies by functional distance approaches. Journal of Regional Science, 11(1), 57-72.

Breukelman, J., Brink, G., de Jong, T., Floor, H. (2009). Manual Flowmap 7.3. Faculty of Geographical Sciences, Utrecht University, The Netherlands. (http://flowmap.geo.uu.nl; dostop: 15. 8. 2010).

Casado-Diaz, J. M. (2000). Local labour market areas in Spain: A case study. Regional Studies, 34, 843-856.

Coombes, M. G., Green, A. E., Openshaw, S. (1986). An efficient algorithm to generate official statistical reporting areas: The case of the 1984 travel-to-work-areas revision in Britain. Journal of the Operational Research Society, 37, 943-953.

Cörvers, F., Hensen, M., Bongaerts, D. (2009). Delimitation and coherence of functional and administrative regions. Regional Studies, 43(1), 19-31.

Drobne, S., Konjar, M., Lisec, A. (2009a). Delimitation of Functional Regions Using Labour Market Approach. V: Zadnik Stirn L., J. Žerovnik, S. Drobne and A. Lisec (ur.), Proceedings of SOR'09, 10th International Symposium on Operational Research in Slovenia. Ljubljana. Slovenian Society Informatika (SDI), Section for Operational Research (SOR), 417-425.

Drobne, S., Lisec, A., Konjar, M., Zavodnik Lamovšek, A., Pogačnik, A. (2009b). Functional vs. Administrative regions: Case of Slovenia. V: Vujošević M. (ur.), Thematic Conference Proceedings. Vol. 1. Belgrade. Institute of Architecture and Urban \& Spatial Planning of Serbia, 395-416.

Drobne, S., Konjar, M., Lisec, A. (2010). Razmejitev funkcionalnih regij Slovenije na podlagi analize trga dela = Delimitation of functional regions of Slovenia based on labour market analysis. Geod. vestn. 54(3), 481-500.

Drobne, S., Konjar, M. (2011). Modeliranje funkcionalnih regij Slovenije s tokovi delavcev vozačev. V: Zavodnik Lamovšek, A. ( ur.), Funkcionalne regije - izziv prihodnjega razvoja Slovenije. Ljubljana, Kamnik. Fakulteta za gradbeništvo in geodezijo, Inštitut za politike prostora, OIKOS - svetovanje za razvoj, 37-52.

ES (2003). Uredba (ES) št. 1059/2003 Evropskega parlamenta in Sveta z dne 26. maja 2003 o oblikovanju skupne klasifikacije statističnih teritorialnih enot (NUTS). Uradni list Evropske unije L 154, str. 1-41. Bruselj.

ES (2007). Poročilo Komisije Evropskemu parlamentu in Svetu o izvajanju uredbe NUTS (Uredba (ES) št. 1059/2003). Bruselj. Komisija Evropskih skupnosti.

Eurostat (2010). Regions in the European Union, Nomenclature of territorial units for statistics (NUTS 2010 - EU-27).

${ }^{3}$ Mišljenih je 12 statističnih/razvojnih regij na ravni NUTS $3 v$ Sloveniji. 
Eurostat (2011). NUTS - Nomenclature of territorial units for statistics. (http://aesop2005.scix.net/cgi-bin/papers/ Show?667; dostop: 1. 5. 2011).

Farmer, C. J. Q. (2009). Data driven functional regions. Geocomputation 2009. November 30th-December 2nd, University of New South Wales, Sydney, Australia.

Farmer, C. J. Q., Fotheringham, A. S. (2011). Network-based functional regions. Environment and Planning A, 43(11), 2723-2741.

Feldman, $O$. ., Simmonds, D., Troll, N., Tsang, F. (2006). Creation of a System of Functional Areas for England and Wales and for Scotland. Cambridge. David Simmonds Consultancy.

Florez-Revuelta, F., Casado-Diaz, J., Martinez-Bernabeu, L. (2008). An evolutionary approach to the delineation of functional areas based on travel-to-work flows. International Journal of Automation and Computing, 5(1), 10-21.

Karlsson C., Olsson, M. (2006). The identification of functional regions: theory, methods, and applications. Ann Reg Sci, 40, 1-18.

Killian, M. S., Tolbert, C. M. (1993). Mapping social and economic space: the delineation of local labour markets in the United States. In: Singelmann, J., Desaran, F.A. ( ur.). Inequalities in Labour Market Areas. Westview, Boulder, 69-79.

Konjar, M. (2009). Modeliranje zaposlitvenih sistemov Slovenije na osnovi dnevne mobilnosti. Diplomska naloga. Ljubljana. Univerza v Ljubljani, Fakulteta za gradbeništvo in geodezijo.

Konjar, M., Lisec, A., Drobne, S. (2010). Methods for delineation of functional regions using data on commuters. In: M. Painho ( ur.), M. Y. Santos ( ur.), H. Pundt ( ur.), Geospatial thinking: proceedings of the 13th AGILE International Conference on Geographic Information Science, 10-14 May 2010 - Guimaraes, Portugal, 1-10.

Laan, L. V. D. (1991). Spatial labour markets in the Netherlands. Eburon.

Laan, L. V. D., Schalke, R. (2001). Reality versus policy: The delineation and testing of local labour market and spatial policy areas. European Planning Studies, 9 (2), 201-221.

Maier, K. (2005). New policy? New regions? New borders? AESOP 2005 Congress, 13-17 July 2005, Vienna, Austria, 9 pp. (http://aesop2005.scix.net/cgi-bin/papers/Show?667; dostop: 25. 2. 2011).

Masser, I., Brown, P. J. B. (1975). Hierarchical aggregation procedures for interaction data. Environment and Planning A, 7(5), 509-523.

Masser, I., Brown, P. J. B. (1977). Spatial representation and spatial interaction. Papers of the Regional Science Association 38, 71-92.

Masser, I., Scheurwater, J. (1980). Functional regionalisation of spatial interaction data: an evaluation of some suggested strategies. Environment and Planning A, 12(12), 1357-1382.

Mitchell, W., Bill, A., Watts, M. (2007). Identifying functional regions in Australia using hierarchical aggregation techniques. Working Paper No. 07-06, Centre of Full Employment and Equity, The University of Newcastle, Australia.

OECD (2002). Redefining territories - The functional regions. Organisation for Economic Co-operation and Development. Paris, France.

OECD (2011). OECD Territorial Reviews: Slovenia 2011. Organisation for Economic Co-operation and Development. OECD Publishing.

Papps, K. L., Newell, J. O. (2002). Identifying functional labour market areas in New Zealand: A reconnaissance study using Travel-to-Work data. Discussion Paper 443, Institute for the Study of Labor (IZA), Bonn.

Persyn, D., Torfs, W. (2011). Functional Labour Markets in Belgium: Evolution over time and intersectoral comparison. Vives Discussion Paper. Katholike Universiteit Leuven. Belgium.

Pogačnik, A., Zavodnik Lamovšek, A., Drobne, S., Žaucer, T., Konjar, M., Trobec, B., Pichler Milanović, N., Pogačar, K., Kešeljević, A., Kosi, A., Miklavčič, T., Zakrajšek, U., Šolc, U., Strmšnik, K., Stres, A. (2009). Analiza razvojnih virov in scenarijev za modeliranje funkcionalnih regij : zaključno poročilo tretje faze. Ljubljana. Fakulteta za gradbeništvo in geodezijo; Maribor. Fakulteta za gradbeništvo; Domžale. Oikos.

Pogačnik, A., Konjar, M., Drobne, S., Zavodnik Lamovšek, A., Soss, K. (2011). Večkriterijska ocena modelov funkcionalnih regij in predlog regionalizacije Slovenije. In: Zavodnik Lamovšek, A. (ur.), Funkcionalne regije - izziv prihodnjega razvoja Slovenije. Ljubljana, Kamnik. Fakulteta za gradbeništvo in geodezijo, Inštitut za politike prostora, OIKOS - svetovanje za razvoj, 67-75. 
Schrerrer, W. (2006). Economic Aspects of a "Middle Layer" of Administration and Government: Some Experience from Austria, Uprava, 4(2-3), 25-34.

Slater, P. B. (1981). Comparisons of aggregation procedures for interaction data: An illustration using a college student international flow table. Socio-Economic Planning Sciences, 15(1), 1-8.

Smart, M. W. (1974). Labour market areas: Uses and definition. Progress in Planning, 2, 239-353.

SORS (2011a). Administrative-territorial division = "Upravno-teritorialna razdelitev", Statistical Office of the Republic of Slovenia, Ljubljana. (http://www.stat.si , Splošno ; dostop: 25. 3. 2011).

SORS (2011b). Persons in employment (excluding farmers) by municipalities of residence and municipalities of workplace by sex, municipalities, Slovenia, annually. Statistical Office of the Republic of Slovenia. Ljubljana. (http:// pxweb.stat.si/pxweb/Database/Municipalities/Municipalities.asp; dostop: 1. 6. 2010)

SORS (2011c). Average monthly gross and net earnings per person in paid employment and persons in employment, 2010, municipalities, Slovenia. Statistical yearbook, Statistical Office of the Republic of Slovenia. Ljubljana. (http:// www.stat.si/letopis/2010/31_10/31-08-10.htm; dostop: 25. 2. 2011)

Tomaney, J., Ward, N. (2000). England and the »New Regionalism«. Regional studies 34(5), 471-478.

Van der Zwan, J., Van der Wel, R., Ritsema Van Eck, J., De Jong, T., Floor, H. (2005). Flowmap version 7.2 Manual. Utrecht. Faculty of Geographical Sciences, Utrecht University, The Netherlands. http://flowmap.geog.uu.nl/(dostop: 1. 7. 2010).

Ward, J. H. (1963). Hierarchical grouping to optimize an objective function. Journal of the American Statistical Association 58(301), 236-244.

Prispelo v objavo: 24. januar 2012

Sprejeto: 2. marec 2012

viš. pred. mag. Samo Drobne, univ. dipl. inž. geod.

Univerza v Ljubljani, Fakulteta za gradbeništvo in geodezijo

Jamova cesta 2, SI-1000 Ljubljana

e-pošta: samo.drobne@fgg.uni-lj.si

prof. dr. Marija Bogataj

Mediteranski inštitut za sodobne študije

Mednarodni prehod 6, SI-5290 Šempeter pri Gorici

e-pošta:marija.bogataj@guest.arnes.si 


\section{Priloga 1: Šifrant občin (regije na ravni SKTE 5) v Sloveniji za obdobje 2000-2010}

\begin{tabular}{|c|c|}
\hline Šifra & \begin{tabular}{|l|} 
Občina \\
\end{tabular} \\
\hline 1 & Ajdovščina \\
\hline 2 & Beltinci \\
\hline 3 & Bled \\
\hline 4 & Bohinj \\
\hline 5 & Borovnica \\
\hline 6 & Bovec \\
\hline 7 & Brda \\
\hline 8 & Brezovica \\
\hline 9 & Brežice \\
\hline 10 & Tišina \\
\hline 11 & Celje \\
\hline 12 & Cerklje na Gorenjskem \\
\hline 13 & Cerknica \\
\hline 14 & Cerkno \\
\hline 15 & Črenšovci \\
\hline 16 & Črna na Koroškem \\
\hline 17 & Črnomelj \\
\hline 18 & Desternik \\
\hline 19 & Divača \\
\hline 20 & Dobrepolje \\
\hline 21 & Dobrova-Polhov Gradec \\
\hline 22 & Dol pri Ljubljani \\
\hline 23 & Domžale \\
\hline 24 & Dornava \\
\hline 25 & Dravograd \\
\hline 26 & Duplek \\
\hline 27 & Gorenja vas-Poljane \\
\hline 28 & Gorišnica \\
\hline 29 & Gornja Radgona \\
\hline 30 & Gornji Grad \\
\hline 31 & Gornji Petrovci \\
\hline 32 & Grosuplje \\
\hline 33 & Šalovci \\
\hline 34 & Hrastnik \\
\hline 35 & Hrpelje-Kozina \\
\hline 36 & Idrija \\
\hline 37 & Ig \\
\hline 38 & Ilirska Bistrica \\
\hline 39 & Ivančna Gorica \\
\hline 40 & Izola/Isola \\
\hline 41 & Jesenice \\
\hline 42 & Juršinci \\
\hline 43 & Kamnik \\
\hline 44 & Kanal \\
\hline 45 & Kidričevo \\
\hline 46 & Kobarid \\
\hline 47 & Kobilje \\
\hline 48 & Kočevje \\
\hline 49 & Komen \\
\hline 50 & \begin{tabular}{|l|} 
Koper/Capodistria \\
\end{tabular} \\
\hline 51 & Kozje \\
\hline 52 & Kranj \\
\hline 53 & Kranjska Gora \\
\hline 54 & Krško \\
\hline 55 & Kungota \\
\hline 56 & Kuzma \\
\hline 57 & Laško \\
\hline 58 & Lenart \\
\hline 59 & Lendava/Lendva \\
\hline 60 & Litija \\
\hline 61 & Ljubljana \\
\hline 62 & Ljubno \\
\hline 63 & Ljutomer \\
\hline 64 & Logatec \\
\hline 65 & Loška dolina \\
\hline 66 & Loški potok \\
\hline 67 & Luče \\
\hline 68 & Lukovica \\
\hline 69 & Majšperk \\
\hline 70 & Maribor \\
\hline 71 & Medvode \\
\hline 72 & Mengeš \\
\hline 73 & Metlika \\
\hline 74 & Mežica \\
\hline 75 & Miren-Kostanjevica \\
\hline 76 & Mislinja \\
\hline 77 & Moravče \\
\hline 78 & Moravske Toplice \\
\hline 79 & Mozirje \\
\hline 80 & Murska Sobota \\
\hline 81 & Muta \\
\hline
\end{tabular}

\begin{tabular}{|c|c|c|c|}
\hline Šifra & Občina & Šifra & Občina \\
\hline 82 & Naklo & 164 & Komenda \\
\hline 83 & Nazarje & 165 & Kostel \\
\hline 84 & Nova Gorica & 166 & Križevci \\
\hline 85 & Novo mesto & 167 & Lovrenc na Pohorju \\
\hline 86 & Odranci & 168 & Markovci \\
\hline 87 & Ormož & 169 & Miklavž na Dravskem polju \\
\hline 88 & Osilnica & 170 & Mirna Peč \\
\hline 89 & Pesnica & 171 & Oplotnica \\
\hline 90 & Piran/Pirano & 172 & Podlehnik \\
\hline 91 & Pivka & 173 & Polzela \\
\hline 92 & Podčetrtek & 174 & Prebold \\
\hline 93 & Podvelka & 175 & Prevalje \\
\hline 94 & Postojna & 176 & Razkrižje \\
\hline 95 & Preddvor & 177 & Ribnica na Pohorju \\
\hline 96 & Ptuj & 178 & Selnica ob Dravi \\
\hline 97 & Puconci & 179 & Sodražica \\
\hline 98 & Rače-Fram & 180 & Solčava \\
\hline 99 & Radeče & 181 & Sveta Ana \\
\hline 100 & Radenci & 182 & Sveti Andraž v Slov. goricah \\
\hline 101 & Radlje ob Dravi & 183 & Šempeter-Vrtojba \\
\hline 102 & Radovljica & 184 & Tabor \\
\hline 103 & Ravne na Koroškem & 185 & Trnovska vas \\
\hline 104 & Ribnica & 186 & Trzin \\
\hline 105 & Rogašovci & 187 & Velika Polana \\
\hline 106 & Rogaška Slatina & 188 & Veržej \\
\hline 107 & Rogatec & 189 & Vransko \\
\hline 108 & Ruše & 190 & Žalec \\
\hline 109 & Semič & 191 & Žetale \\
\hline 110 & Sevnica & 192 & Žirovnica \\
\hline 111 & Sežana & 193 & Žužemberk \\
\hline 112 & Slovenj Gradec & & Nova občina v letu 2002 \\
\hline 113 & Slovenska Bistrica & 194 & Smartno pri Litiji \\
\hline 114 & Slovenske Konjice & & Nove občine v letu 2006 \\
\hline 115 & Starše & 195 & Apače \\
\hline 116 & Sveti Jurij & 196 & Cirkulane \\
\hline 117 & Šenčur & 197 & Kostanjevica na Krki \\
\hline 118 & Šentilj & 198 & Makole \\
\hline 119 & Šentjernej & 199 & Mokronog-Trebelno \\
\hline 120 & Šentjur pri Celju & 200 & Poljčane \\
\hline 121 & Škocjan & 201 & Renče-Vogrsko \\
\hline 122 & Škofja Loka & 202 & Središče ob Dravi \\
\hline 123 & Škofljica & 203 & Straža \\
\hline 124 & Šmarje pri Jelšah & 204 & Sveta Trojica v Slovenskih goricah \\
\hline 125 & Śmartno ob Paki & 205 & Sveti Tomaž \\
\hline 126 & Šššanj & 206 & Šmarješke Toplice \\
\hline 127 & Store & 207 & Gorje \\
\hline 128 & Tolmin & 208 & Log-Dragomer \\
\hline 129 & Trbovlje & 209 & Rečica ob Savinji \\
\hline 130 & Trebnje & 210 & Sveti Jurij v Slovenskih goricah \\
\hline 131 & Tržič & 211 & Sentrupert \\
\hline
\end{tabular}

\begin{tabular}{|l|l|}
\hline 133 & Velenje \\
\hline 134 & Velike Lašč \\
\hline 135 & Videm \\
\hline 136 & Vipava \\
\hline 137 & Vitanje \\
\hline 138 & Vodice \\
\hline 139 & Vojnik \\
\hline 140 & Vrhnika \\
\hline 141 & Vuzenica \\
\hline 142 & Zagorje ob Savi \\
\hline 143 & Zavrč \\
\hline 144 & Zreče \\
\hline 146 & Železniki \\
\hline 147 & Žiri \\
\hline 148 & Benedikt \\
\hline 149 & Bistrica ob Sotli \\
\hline 150 & Bloke \\
\hline 151 & Braslovče \\
\hline 152 & Cankova \\
\hline 153 & Cerkvenjak \\
\hline 154 & Dobje \\
\hline 155 & Dobrna \\
\hline 156 & Dobrovnik/Dobronak \\
\hline 157 & Dolenjske Toplice \\
\hline 158 & Grad \\
\hline 159 & Hajdina \\
\hline 160 & Hoče-Slivnica \\
\hline 161 & Hodoš/Hodos \\
\hline 162 & Horjul \\
\hline 163 & Jezersko \\
\hline & \\
\hline
\end{tabular}

